\title{
Bioinformatics in New Generation Flavivirus Vaccines
}

\author{
Penelope Koraka, Byron E. E. Martina, and Albert D. M. E. Osterhaus \\ Department of Virology, Erasmus Medical Centre, 3000 CA Rotterdam, The Netherlands \\ Correspondence should be addressed to Albert D. M. E. Osterhaus, a.osterhaus@erasmusmc.nl
}

Received 2 October 2009; Revised 21 December 2009; Accepted 2 March 2010

Academic Editor: Yongqun Oliver He

Copyright () 2010 Penelope Koraka et al. This is an open access article distributed under the Creative Commons Attribution License, which permits unrestricted use, distribution, and reproduction in any medium, provided the original work is properly cited.

\begin{abstract}
Flavivirus infections are the most prevalent arthropod-borne infections world wide, often causing severe disease especially among children, the elderly, and the immunocompromised. In the absence of effective antiviral treatment, prevention through vaccination would greatly reduce morbidity and mortality associated with flavivirus infections. Despite the success of the empirically developed vaccines against yellow fever virus, Japanese encephalitis virus and tick-borne encephalitis virus, there is an increasing need for a more rational design and development of safe and effective vaccines. Several bioinformatic tools are available to support such rational vaccine design. In doing so, several parameters have to be taken into account, such as safety for the target population, overall immunogenicity of the candidate vaccine, and efficacy and longevity of the immune responses triggered. Examples of how bio-informatics is applied to assist in the rational design and improvements of vaccines, particularly flavivirus vaccines, are presented and discussed.
\end{abstract}

\section{Introduction}

Flavivirus infections are among the most important viral pathogens of humans and animals, causing significant morbidity and mortality. They belong to genus Flavivirus of the family Flaviviridae. Flaviviruses are transmitted via arthropods and are classified into mosquito-borne and tickborne flaviviruses. These groups of viruses are distinct not only by their modes of transmission, but also phylogenetically and by the clinical manifestations of the infections they cause [1]. Tick-borne flaviviruses are mainly associated with encephalitis and comprise a group of closely related viruses, which collectively belong to the tick-borne encephalitis (TBE) complex. The TBE complex comprises the Powassan virus, Louping ill virus, Kyasanur Forest disease virus, Omsk hemorrhagic fever virus, Langat virus and the Tick-Borne encephalitis viruses (TBEV). The TBEV species includes three subtypes which are all known to cause encephalitis in humans: Western European (previously known as Central European Encephalitis or CEE), Far Eastern (previously known as Russian Spring and Summer Encephalitis or RSSE), and Siberian (previously west-Siberian). Mosquitoborne flaviviruses are further divided based on phylogenetic and antigenic differences. The Japanese encephalitis serocomplex includes Japanese encephalitis virus (JEV), West Nile virus (WNV) and Saint Louis encephalitis virus (SLEV). The Dengue virus (DENV) group comprises an independent serogroup of four closely related but antigenically distinct serotypes. Finally, yellow fever virus (YFV), the prototype of flaviviruses, constitutes an independent serogroup [2].

The majority of flavivirus infections are manifested by mild acute febrile syndromes. A low percentage of infected individuals may develop severe neurological, hepatic and/or hemorrhagic disease with high mortality rates. JEV causes frequent outbreaks of meningo-encephalitis in Asia, affecting mainly children [3]. WNV may also cause severe outbreaks of meningo-encephalitis, with outbreaks confined to West Africa, Middle-East, and since 1999 also in North America. WNV is now spreading all over the Americas, posing a risk to millions of people [4]. DENV is endemic throughout tropical and subtropical areas of the world where more than 2.5 billion people are at risk of infection. Infection with DENV may result in development of hemorrhagic manifestations and/or shock in untreated patients [5]. YFV causes serious infections manifested by fulminant hepatitis and severe hemorrhagic disease. YFV still kills a considerable 
number of people annually, despite the availability of an effective vaccine [6].

Flaviviruses are relatively small (approx. $11 \mathrm{~kb}$ ) positive single-stranded RNA viruses coding for three structural (Capsid, C; Precursor membrane, prM; and envelope, E) and seven nonstructural proteins (Figure $1(\mathrm{a})$ ). The single open reading frame (ORF) is flanked by $5^{\prime}$ and $3^{\prime}$ untranslated regions (UTR), the structures of which are important in viral replication [7]. The E protein is the major component of the virus bearing sites for attachment and fusion with the host cells and induction of immune responses. Several $\mathrm{B}$ - and $\mathrm{T}$ cell epitopes have been recognized on the $\mathrm{E}$ protein $[8,9]$. The $\mathrm{E}$ protein of flaviviruses forms a headto-tail dimer both in solution and on the viral membrane surface, with each monomer divided into three domains (D I, II, and III, Figure 1(b)). DI folds into an eight-stranded antiparallel $\beta$-barrel, containing about 120 residues and divided in three segments. The two long loops between these three segments form the dimerization DII, which contains the fusion peptide. DIII contains the carboxyterminal 100 amino acids that form seven antiparallel $\beta$ sheets. In contrast to DI and DII, this domain represents an independently folding domain that can be expressed as a recombinant protein. Studies on the B cell repertoire upon flavivirus infection suggest that the human antibody response is predominantly directed to epitopes located in DII $[10,11]$. However, antibodies specific to epitopes in DII have been shown to be weakly neutralizing, highly cross-reactive with other flaviviruses, and nonprotective in animal models. On the other hand, the potent, type-specific, neutralizing epitopes are located in the upper lateral surface of DIII [12-14]. Mutations in the DIII region have been associated with attenuated virulence or the ability of virus to escape specific neutralization, suggesting a role of DIII in receptor recognition [15]. Flavivirus infection triggers both innate and adaptive immunity in naïve individuals. In animal models, adaptive immune responses have been shown to play an important role in controlling primary WNV infection as exemplified by the high viral loads and high mortality observed in IgM deficient mice. It has been shown that the level of WNV-specific IgM at day four after infection has a prognostic value [16]. The role of IgM in controlling infection with other flaviviruses is however still unclear. Although T-helper (CD4+) and T-cytotoxic (CD8+) cells have been shown to play a role in controlling infection of mice with either WNV $[17,18]$ or DENV [19], the presence of antibodies is generally considered more relevant in terms of vaccine-induced protection.

For vector-borne viruses it is reasonable to assume that effective vector control would greatly reduce the morbidity of infection with such viruses. In the case of flaviviruses, mosquito control has at least in the long run, proven to be largely ineffective [20-22]. For example, efforts to eradicate the mosquito vectors of DENV during the 1970's were successful and resulted in the disappearance of the virus from the region. However, as soon as these programs were discontinued, Ae. aegypti (the main vector for urban transmission of DENV) re-infested the region, which coincided with the re-emergence of DENV. Therefore, vaccination against these pathogens may be the most efficient and effective way to control disease. In fact, one of the most effective vaccines ever developed is the live-attenuated vaccine against YFV [23]. This vaccine was developed in the late 1930's by Theiler and co-workers and although the correlates of protection even today are not completely clear, it has been used to immunize and protect more than 400 million people against yellow fever. Also licensed vaccines against JEV and TBEV infections in humans exist. Routine childhood immunization against JEV has eliminated the disease from many Asian countries, whereas the disease continues to cause devastating outbreaks in countries where the vaccine is not used. The mouse brainderived inactivated vaccine is relatively expensive to produce and the lack of long-term immunity and risk of allergic reactions makes large-scale vaccination with this vaccine, especially in Asia where it is most needed, not feasible. Cell culture-derived inactivated and live-attenuated JEV vaccines have been extensively used in China, but purity of these vaccine preparations represents the main hurdle for approval of these vaccines in Western countries. More recently a cellderived, alum-adjuvanted JEV vaccine was licensed for use in adults in USA and some EU member states. However, the longevity of the immune response to this vaccine is not yet established. For other important flavivirus such as WNV and DENV, no vaccine is available yet.

This review aims to give a brief overview of flavivirus vaccine candidates and discuss how bio-informatics can assist in the rational design and improvements of vaccines. In doing so we will discuss examples of how bioinformatics has been or could be used in the development of novel generations flavivirus vaccines. It is beyond the scope of this review to summarize the recent advances in immunoinformatics for the prediction of $\mathrm{T}$ and $\mathrm{B}$ cell epitopes and the interaction of proteins with the immune system (the reader is referred to the excellent review of Brusic et al. [24] and the references therein).

\section{Rational Design of Flavivirus Vaccines}

We have entered a new era of vaccine development, where rational design of candidate vaccines has replaced the trial-and-error approach. Undoubtedly, the trial-and-error approach has been successful in the past as exemplified by the success of the YFV vaccine, one of the most effective vaccines ever developed. Rational design of vaccines is a step-wise approach as depicted in Figure 2: (1) identify target antigen(s), (2) determine the vaccine platform, (3) optimize factors for gene expression, (4) produce and characterize vaccine, (5) test safety, immunogenicity and efficacy in animal models. The recent advances in molecular biology and bio-information technology have contributed significantly to our understanding of viral structure, viral replication, attenuation, and determinants of pathogenicity. Understanding these aspects are crucial for identifying target proteins. Several bio-informatic tools are available that can help in the process of antigen identification. The majority of bioinformatic tools used in computational vaccinology however, focus on antigen presentation and processing, with the ultimate goal to map T and B cell epitopes (step 5). Although 


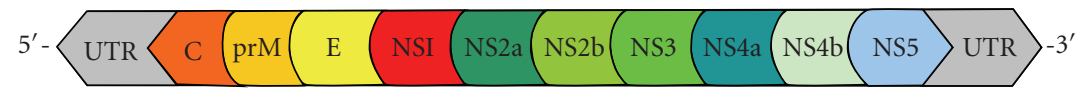

(a)

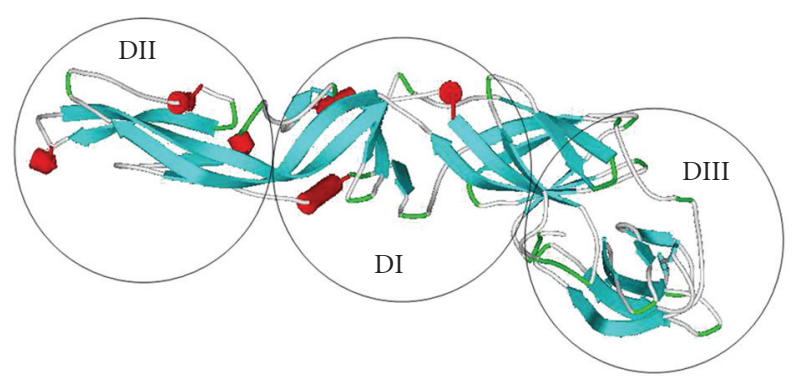

(b)

FIgURe 1: (a) Flavivirus genomic RNA encoding one long ORF cleaved co- and post-translationally into three structural and seven nonstructural proteins. The viral genome is flanked by $5^{\prime}$ and $3^{\prime}$ UTRs which play an important role in virus transcription and replication. (b) Three dimensional structure of the monomeric form of the E protein of DENV-2. Each monomer is divided into three discernable domains (DI, II and III). Serocomplex and group specific cross reactive epitopes are mainly located on DI and II. DIII is the receptor binding domain and contains mainly type specific epitopes. The potent neutralizing epitopes are located at the lateral site of DIII.

the mapping and identification of highly immunogenic epitopes on target antigens is important, several additional steps need to be considered when embarking on rational design of new generation vaccines against these viruses (step 2 and 3). Common problems encountered during development of vaccines include low yields of proteins and consequently low immunogenicity.

\section{Inactivated and Subunit Candidate Vaccines}

The great impact that flavivirus infections have on public health and the fact that prevention is difficult to achieve through vector control have made the development of flavivirus vaccines essential for long-term control and elimination of these infections, and reduction of the associated morbidity and mortality. The currently available vaccines against YFV, JEV and TBEV have proven to be quite successful. Efforts are ongoing to develop safe and effective vaccines against the other medical important flaviviruses. In addition efforts aiming to improve the existing ones are ongoing. Almost all vaccine platforms have been used in the development of candidate flavivirus vaccines, ranging from whole inactivated, live-attenuated, subunit, DNA and vectored candidate vaccines (summarized in Table 1). The currently licensed vaccines against JEV and TBEV contain formalininactivated whole virus, purified from mouse brains [25] (JEV) or cultured cells (JEV, TBEV). Studies to compare the safety and immunogenicity of candidate vaccines based on cell-derived inactivated JEV show promising results $[26,27]$. This formalin-inactivated JEV vaccine is now licensed in the USA and EU for use in adults. However, the duration of immunity and the need for booster vaccination needs to be further investigated [28]. There are several concerns with the use of inactivated vaccines. They are expensive, require two or three doses to achieve protective efficacy, and perhaps more importantly, require further booster doses to maintain immunity [29]. Therefore, large scale use of inactivated flavivirus vaccines for humans may prove problematic due to the need of an adjuvant to potentiate the immune response and to provide long-lasting immunity. Furthermore, formalin-inactivation may pose other safety concerns as has been shown in case of respiratory syncytia virus and human metapneumo virus [30, 31], although extensive use of formalin-inactivated JEV and TBEV vaccines does not corroborate this concern.

Subunit flavivirus vaccines, expressing recombinant E protein, combination of prM-E or DIII alone, have been shown to be effective and immunogenic in animal models $[32,33]$. The minimalistic approach of using DIII alone instead of full length $\mathrm{E}$ protein is based on the observations that DIII contains epitopes responsible for type specific neutralization, whereas DI and DII contain epitopes responsible for cross-neutralization and/or sensitivity to disease enhancement $[10,11]$. Because DIII is poorly immunogenic, the use of an adjuvant is necessary for efficient induction of immune responses.

A common problem of inactivated and subunit vaccines is the poor immunogenicity when compared to liveattenuated vaccines. Given the safety issues often associated with the use of live-attenuated vaccines, modern vaccinology also focuses on the improvement of the immunogenicity of inactivated and subunit vaccine candidates. Until recently aluminium hydroxide (Alum) was the only adjuvant registered for human use. Alum triggers antibody responses and T-helper 2 responses, but no $\mathrm{CD} 8+\mathrm{T}$ cell immune responses. Increasing understanding of the mechanisms that leads to protective versus detrimental immune responses will be instructive in the rational choice and design of novel adjuvants. For example, the activation of several Toll like receptors (TLR) has been shown to stimulate innate and orchestrate adaptive immune responses via stimulation of antigen presenting cells. Several studies have shown the potential of TLRs agonists as effective adjuvants [3436]. CpG oligodeoxynucleotides were shown to be potent 


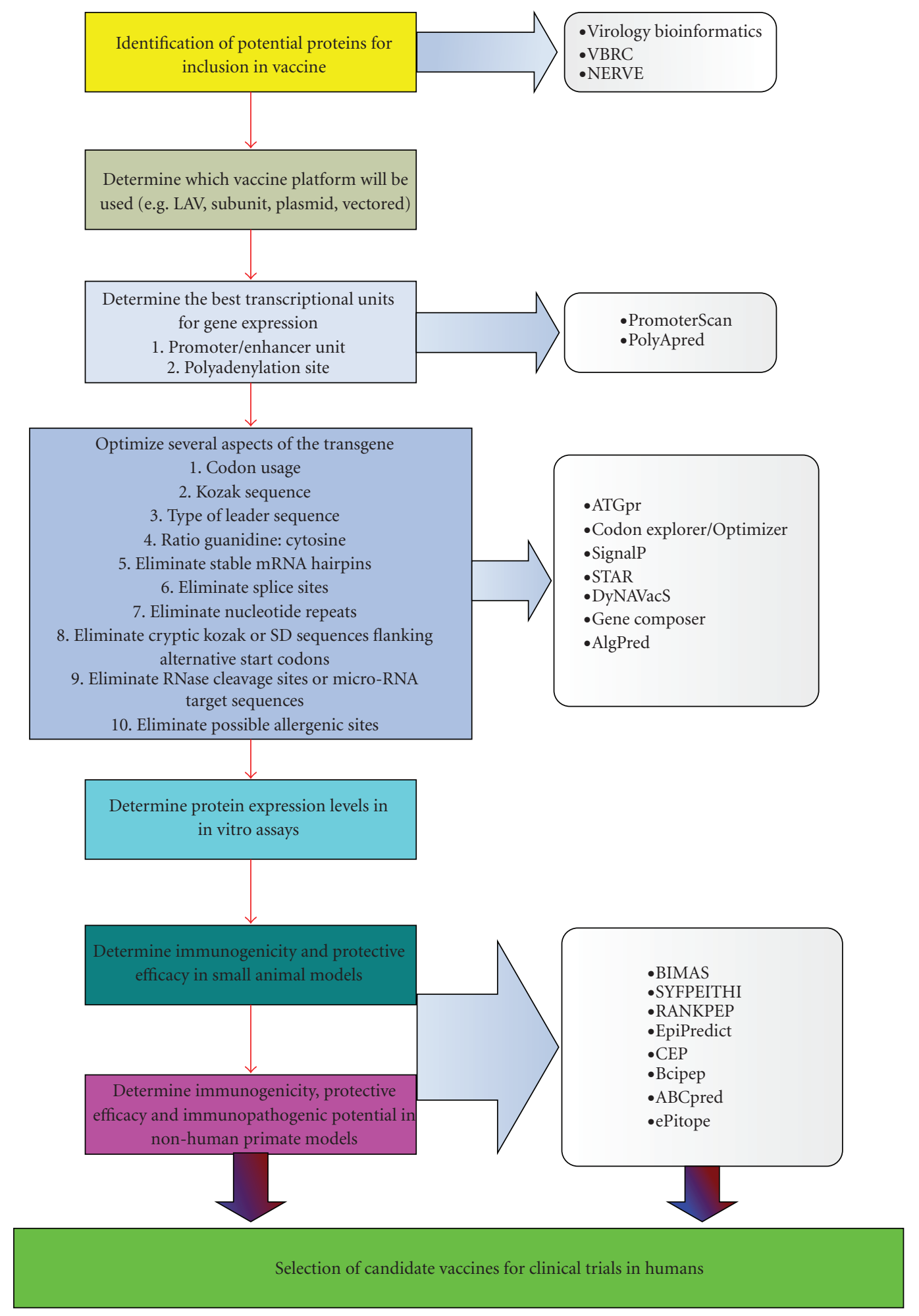

FIGURE 2: Steps involved in the rational design of vaccines. A number of parameters should be taken into account from choosing the right immunogen until the selection of candidate vaccines for clinical trials. Several bioinformatics tools can be applied in this process to assist in the improvement of antigen selection, maximizing expression, determination of immunogenicity and selection of candidate vaccines. 
TABLE 1: Summary of flavivirus candidate vaccines based on different vaccine platforms.

\begin{tabular}{|c|c|c|c|}
\hline Type of vaccine & Virus & Antigen & Comments \\
\hline \multirow{3}{*}{ Inactivated/killed } & JEV & Whole virus & Licenced for human use \\
\hline & DENV-2 & Whole virus & Pre clinical studies in mice and non-human primates \\
\hline & WNV & E, prM, whole virus & Low immunogenicity, use of adjuvant necessary \\
\hline \multirow{4}{*}{ Subunit } & DENV-2 & D III, NS1, E protein & Immunogenicity tested only in mice \\
\hline & DENV-4 & C-M-E-NS1 & Immunogenicity tested only in mice \\
\hline & WNV & D III, E protein, NS1 & Low immunogenicity, only tested in mice \\
\hline & JEV & prM-E & Immunogenicity tested only in mice \\
\hline \multirow{3}{*}{ DNA } & DENV & prM-E, NS1 & Low immunogenicity \\
\hline & JEV & $\mathrm{E}$ & Low immunogenicity \\
\hline & WNV & E, prM, C & Low immunogenicity \\
\hline \multirow{4}{*}{ Live attenuated } & YFV & & Licenced for human use \\
\hline & Mono- and tetravalent DENV & & Phase I, and II clinical trials ongoing \\
\hline & JEV & & Phase I and II clinical trials conducted \\
\hline & WNV & & \\
\hline Vectored & WNV & E, prM & Vectors used: MVA, MV, AdV, pox-, alphaviruses \\
\hline
\end{tabular}

stimulators of TLR-9 and able to significantly enhance both the humoral and cellular immune responses to several viruses in mice $[37,38]$. Furthermore, the use of CpG resulted in substantial reduction of the antigen dose needed in several models. Several programs (e.g., DyNAVacS, Table 2) allow optimization of $\mathrm{CpG}$ content in the gene of interest, which may enhance vaccine immunogenicity. An interesting development in this field is the availability of a database (TollML) to retrieve and deposit agonists for the different TLR (Table 2). In this database, the known structural motifs of TLRs are deposited allowing for structural modelling of other TLRs. Furthermore the ligands of TLRs can be easily retrieved. Elucidation of the crystal structure of TLRs and improvement of powerful bioinformatics tools for protein homology and $a b$ intitio modelling will allow structure-based design of safe and effective TLR agonists that could be subsequently used as adjuvants for vaccines [3941]. The potential of such adjuvants was recently demonstrated in a study that reported how the poorly immunogenic DIII of WNV was remarkably more immunogenic in mice when fused with the TLR-5 agonist flagellin [42].

\section{Live-Attenuated Vaccine Candidates}

In light of the safety issues that may be related with the use of current experimental adjuvants, the concept of using live-attenuated or vectored vaccines is more and more preferred over that of inactivated or subunit vaccines. The current vaccine against YFV is a live-attenuated whole virus vaccine, which has been shown to be safe and highly effective. The advantage of live-attenuated vaccines is that both antibody and $\mathrm{T}$ cell responses are induced, although, there may be risks related to the use of live-attenuated vaccines [43]. For instance, the efforts for the development of a successful vaccine against DENV have mainly focused on the attenuation of the four DENV serotypes through several passages in cell culture and use of these viruses in monovalent or multivalent formulations. The leading hypothesis to explain pathogenesis of DENV infections is the antibody-dependent enhancement of infection (ADE), which suggests that cross reactive subneutralizing antibodies may enhance the infection of target cells, rather than protect them against infection [5]. Since the borderline between protective immunity and disease enhancing immunity is not well defined, the most effective vaccine against DENV would be one that confer solid immunity against all four serotypes. A live-attenuated tetravalent DENV vaccine candidate has been shown to be immunogenic in flavivirus naïve and immune nonhuman primates $[44,45]$, whereas phase I and II clinical trials in humans have shown promising results [46-48]. The molecular basis for attenuation of wild type virus through passage on cell cultures or in animals is usually not understood. A more rational way of generating live-attenuated vaccines is by understanding correlates of virulence. Several algorithms have been designed and are available either free online or as commercial software programs to aid in the prediction of secondary structures of RNA (Table 2). The secondary structures of the $5^{\prime}$ and $3^{\prime}$-UTRs of several flaviviruses, including YFV, DENV, and TBEV have been predicted and conserved structural elements that are important in viral replication were identified [4952]. In a series of studies with DENV-4, the secondary structure of wild type viruses were predicted and subsequent studies were designed to create deletion mutants lacking structural elements that could influence viral replication. It was indeed shown that when a 30 -nucleotide region was deleted, the mutant virus was attenuated and had lost its ability to be transmitted by Ae. aegypti. Subsequently it was shown that these mutant viruses were able to induce strong immune responses in rhesus macaques and in humans, similar to what is seen with wild type viruses $[53,54]$. The success of the DENV-4 $\Delta 30$ was followed by similar results using a DENV-1 $\Delta 30$ mutant virus in vaccination trials of humans and nonhuman primates [55]. In the same line of 
TABLE 2: Selection of servers and programs that could assist in the rational design of vaccines.

\begin{tabular}{|c|c|c|c|}
\hline Server & Web address & Server description & Availability \\
\hline ORF-FINDER & http://www.ncbi.nlm.nih.gov/projects/gorf/ & $\begin{array}{l}\text { Program identifies open } \\
\text { reading frames in a } \\
\text { genome. }\end{array}$ & Free online \\
\hline GeneMark & http://exon.biology.gatech.edu/ & $\begin{array}{l}\text { A set of gene prediction } \\
\text { servers for prokaryotes, } \\
\text { eukaryotes and viruses }\end{array}$ & Free online \\
\hline NERVE & http://www.bio.unipd.it/molbinfo/ & $\begin{array}{l}\text { In silico prediction of } \\
\text { vaccine candidates from } \\
\text { complete proteomes of } \\
\text { bacterial pathogens }\end{array}$ & $\begin{array}{l}\text { Free for } \\
\text { download }\end{array}$ \\
\hline Gene Composer & http://www.genecomposer.net/ & $\begin{array}{l}\text { Gene Composer is a } \\
\text { software program for } \\
\text { rational design or } \\
\text { optimization of genes }\end{array}$ & $\begin{array}{l}\text { Free demo for } \\
1 \text { year }\end{array}$ \\
\hline PromoterScan & http://www-bimas.cit.nih.gov/molbio/proscan/ & $\begin{array}{l}\text { Predicts Promoter regions } \\
\text { based on scoring } \\
\text { homologies with putative } \\
\text { eukaryotic Pol II promoter } \\
\text { sequences }\end{array}$ & Free online \\
\hline ATGpr & http://flj.hinv.jp/ATGpr/atgpr/index.html & $\begin{array}{l}\text { A program for identifying } \\
\text { the initiation codons in } \\
\text { cDNA sequences }\end{array}$ & Free online \\
\hline PolyApred & http://www.imtech.res.in/raghava/polyapred/ & $\begin{array}{l}\text { PolyApred is a SVM based } \\
\text { method for the prediction } \\
\text { of polyadenylation signal in } \\
\text { human DNA sequence. }\end{array}$ & Free online \\
\hline NetGene2 & http://genome.cbs.dtu.dk/services/NetGene2/ & $\begin{array}{l}\text { Predictions of splice sites in } \\
\text { human }\end{array}$ & Free online \\
\hline SignalP & http://www.cbs.dtu.dk/services/SignalP/ & $\begin{array}{l}\text { Signal peptide and cleavage } \\
\text { sites in prokaryotic and } \\
\text { eukaryotic sequences }\end{array}$ & Free online \\
\hline Optimizer & http://genomes.urv.es/OPTIMIZER/ & $\begin{array}{l}\text { A web server for } \\
\text { optimization of codon } \\
\text { usage of a DNA sequence to } \\
\text { increase its expression level. }\end{array}$ & Free online \\
\hline CodonExplorer & http://bmf2.colorado.edu/codonexplorer/index.psp & $\begin{array}{l}\text { Online tool for analyzing } \\
\text { GC content and codon } \\
\text { usage frequency }\end{array}$ & $\begin{array}{l}\text { Free online, } \\
\text { registration } \\
\text { required }\end{array}$ \\
\hline STAR & http://biology.leidenuniv.nl/ batenburg/STROrder.html & $\begin{array}{l}\text { STAR simulates the folding } \\
\text { pathway of RNA and is able } \\
\text { to predict formation of } \\
\text { pseudoknots formation }\end{array}$ & $\begin{array}{l}\text { Commercially } \\
\text { available }\end{array}$ \\
\hline VIENNA package & http://rna.tbi.univie.ac.at/cgi-bin/RNAfold.cgi & $\begin{array}{l}\text { RNAfold predicts } \\
\text { secondary structure of } \\
\text { single stranded RNA or } \\
\text { DNA based on minimum } \\
\text { free energy predictions }\end{array}$ & $\begin{array}{l}\text { Commercially } \\
\text { available }\end{array}$ \\
\hline mFOLD & http://mfold.bioinfo.rpi.edu/ & $\begin{array}{l}\text { Prediction of RNA and } \\
\text { DNA secondary structure } \\
\text { based on thermodynamic } \\
\text { methods }\end{array}$ & Free online \\
\hline DyNAVacS & http://miracle.igib.res.in/dynavac/ & $\begin{array}{l}\text { An integrative tool for } \\
\text { optimized DNA vaccine } \\
\text { design }\end{array}$ & Free onliune \\
\hline AlgPred & http://www.imtech.res.in/raghava/algpred/ & $\begin{array}{l}\text { Algpred allows prediction } \\
\text { of allergens based on } \\
\text { similarity of known epitope } \\
\text { with any region of protein }\end{array}$ & Free online \\
\hline
\end{tabular}


Table 2: Continued.

\begin{tabular}{|c|c|c|c|}
\hline Server & Web address & Server description & Availability \\
\hline BIMAS & http://www-bimas.cit.nih.gov/molbio/hla_bind/ & $\begin{array}{l}\text { Server for prediction of } \\
\text { MHC-I epitopes }\end{array}$ & Free online \\
\hline EpiPredict & http://www.imtech.res.in/raghava/mhc2pred/ & $\begin{array}{l}\text { Software to predict } \\
\text { HLA-class II restricted T } \\
\text { cell epitopes and ligands }\end{array}$ & Free online \\
\hline SYFPEITHI & http://www.syfpeithi.de/ & $\begin{array}{l}\text { Server for prediction of } \\
\text { MHC-I and MHC-II } \\
\text { epitopes }\end{array}$ & Free online \\
\hline RANKPEP & http://bio.dfci.harvard.edu/RANKPEP/ & $\begin{array}{l}\text { Server for prediction of } \\
\text { MHC-I and MHC-II } \\
\text { epitopes }\end{array}$ & Free online \\
\hline CEP & http://202.41.70.74:8080/cgi-bin/cep.pl & $\begin{array}{l}\text { Server for prediction } \\
\text { conformational B cell } \\
\text { epitopes }\end{array}$ & Free online \\
\hline Bcipep & http://www.imtech.res.in/raghava/bcipep/pep_src.html & $\begin{array}{l}\text { Bcipep is a database with a } \\
\text { collection of immunogenic } \\
\text { B cell peptides }\end{array}$ & Free online \\
\hline ABCpred & http://www.imtech.res.in/raghava/abcpred/ & $\begin{array}{l}\text { Server for prediction } \\
\text { conformational B cell } \\
\text { epitopes }\end{array}$ & Free online \\
\hline ePitope & http://www.epitope-informatics.com/ & $\begin{array}{l}\text { Server for prediction linear } \\
\text { B cell epitopes }\end{array}$ & $\begin{array}{l}\text { Online, } \\
\text { commercial }\end{array}$ \\
\hline TollML & http://tollml.lrz.de/ & $\begin{array}{l}\text { A user-friendly database to } \\
\text { retrieve sequence and } \\
\text { structural data as well as } \\
\text { ligands for TLRs. }\end{array}$ & Free online \\
\hline Virology Bioinformatics & http://www.bioinfo.de/isb/2008/08/0008/ & $\begin{array}{l}\text { A collection of } \\
\text { bioinformatic tools for } \\
\text { virology research }\end{array}$ & Free online \\
\hline VBRC & http://athena.bioc.uvic.ca/ & $\begin{array}{l}\text { VBRC provides access to } \\
\text { viral genomes and a variety } \\
\text { of bioinformatic tools for } \\
\text { comparative genomic } \\
\text { analyses }\end{array}$ & Free online \\
\hline
\end{tabular}

research, DENV-2 and DENV-3 $\Delta 30$ mutants were found to be under-attenuated [56, 57]. Using prediction algorithms for secondary structure of RNA a larger region in the 3'UTR of DENV-3 was defined as possibly associated with attenuation and the new mutant virus that was engineered based on these predictions showed a much more promising phenotype in preclinical studies [58]. Similarly, prediction of RNA secondary structure of YFV strains revealed differences between attenuated vaccine strains and wild type viruses. In particular, the conserved long stable hairpin (LSH, a crucial structural element for virus replication) was shorter in vaccine strains than in wild type viruses [50]. As depicted in Figure 3, a 30-nt deletion in the 3'UTR of DENV-3 results in altered secondary structure of the RNA and possibly loss of structural elements necessary for replication. These examples demonstrate that in silico simulation of RNA secondary structure of viral genomes could be a first step in rational design of candidate vaccines. Similarly, it has been shown that the nucleotide sequence of the attenuated YFV vaccine strain differs only 68 nucleotides (translated in 32 amino acid differences) from the parental wild type virulent strain, suggesting that some of these mutations might be associated with virulence and attenuation [59]. The advances in reverse genetics technology allow construction of recombinant viruses with the desired mutations. Such mutant viruses are attractive attenuated vaccine candidates, which could also be used as vectors to express genes of interest, or serve as backbones for chimeric vaccines.

\section{DNA and Vectored Vaccine Candidates}

A common problem encountered during the development of DNA and some vectored vaccines is the low immunogenicity of such vaccine candidates. Variation in transgene stability and level of protein expression are typically attributed to properties of the promoter elements and recombinant gene.

\subsection{Transcriptional Regulator}

5.1.1. Promoter. Molecular biology has made a significant contribution to the development of new generation vaccines. Among the first steps in development of novel generation vaccines is the cloning and expression of genes that encode 


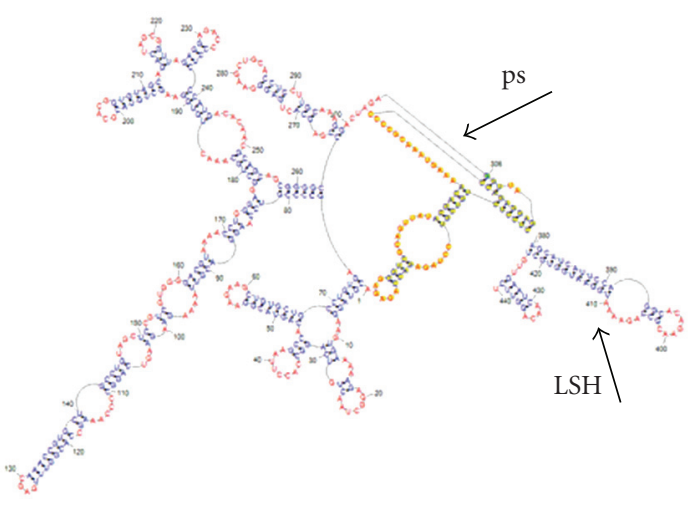

(a)

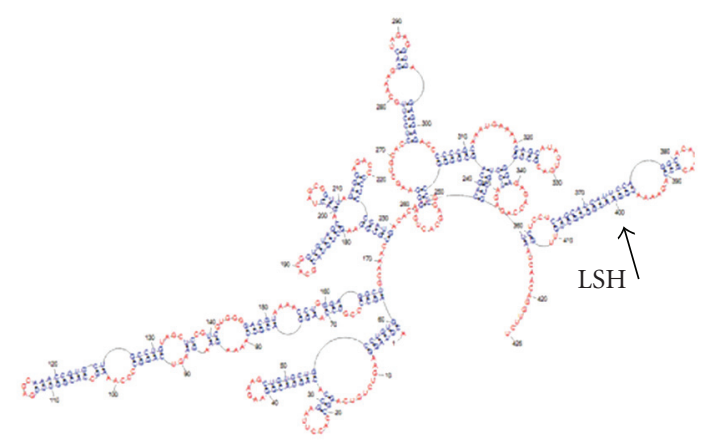

(b)

FIgure 3: Prediction of RNA secondary structure of the $3^{\prime} \mathrm{UTR}$ of DENV-3 strain H87 (DENV-2 Jamaica strain) using the GA algorithm included in the STAR software package. In the top panel is depicted the predicted structure of the naturally occurring strain (shown with arrows the predicted pseudoknot and the conserved LSH structures), bottom panel: predicted structure after in silico introduction of a 29-nt deletion in the proximal part of the UTR. The LSH is preserved but the pseudoknot is lost after deletion. LSH: long stable hairpin, ps: pseudoknot.

highly immunogenic proteins of the virus. Several plasmids have been designed for cloning and expression of both prokaryotic and eukaryotic genes (Figure 4(a)). Obviously, the choice of plasmid for cloning of the genes of interest depends on the type of vaccine platform which is envisaged: subunit, DNA, or vectored. For example, in case of subunit vaccines, it is imperative for the antigen used in the vaccine to resemble its native form as much as possible. Therefore, it is important to realize that posttranslational modifications, which differ between prokaryotes and eukaryotes may affect the formation of B cell epitopes. For DNA and vectored vaccines it is well appreciated that antigen expression levels, determined at both the transcriptional and translational level, affect immunogenicity and efficacy of vaccines. Promoter and enhancer elements affect the levels of messenger RNA (mRNA) available, which have a significant impact on the protein expression levels. The human cytomegalovirus (CMV) immediate-early and the simian virus 40 (SV40) early promoters are the most commonly used transcriptional regulators. Several studies have shown that virus-derived promoters, including the CMV, SV40, and Rous sarcoma virus (RSV), are stronger than other eukaryotic promoters [60] in driving gene expression. In particular the CMV promoter has been shown to be a potent regulator of transcription compared to most other viral promoters [60]. The sensitivity of the CMV promoter to inactivation by cytokines and methylation, especially in muscle tissues [6163 ], in addition to the regulatory problems that may be associated with the use of transcriptional elements derived from pathogenic viruses, have prompted the search and use of other potent promoters. Promoter regions can be predicted in silico in a given sequence and/or vector (Table 2 ). To this end, mammalian promoters including $\beta$-actin [64], human Muscle Creatine-Kinase (MCK) [65], human elongation factor $1 \alpha(\mathrm{EF}-1 \alpha)$ [66], human phosphoglycerate kinase-1 (PGK) [67], major histocompatibility class II [68], human telomerase reverse transcriptase (TRT) [69-71], and tissue plasminogen activator ( $\mathrm{tPA}$ ) [72] promoters have been tested. It is important to realize that promoters may regulate expression of genes in all cell types (ubiquitous) or they may express tissue-specific activity. Therefore, careful consideration must be given to the selection of the promoter driving transgene expression. For instance, while CMV promoter drives transient, but high-level expression of proteins, RSV promotes high-levels of gene expression for a longer time. Therefore, the eukaryotic promoter EF- $1 \alpha$, which provides long-term and high-level gene expression [73] may represent an alternative to viral promoters like RSV. Their activity may be increased by the addition of introns upstream the gene sequence as exemplified by CMV driven vectors [74-77]. This increase in protein expression has been attributed to the presence of enhancer elements in the intron sequence and increased rate of polyadenylation and RNA splicing [77]. However, inclusion of an intron sequence must be applied with caution as it may also lead to aberrant splicing [78]. The use of programs that predict splicing (Table 2) in the context of promoter and intron could help in the rational design or choice of transcriptional units that do not result in aberrant gene splicing. The use of synthetic promoter/enhancer sequences from different sources has also proven to be promising. For example the CAG promoter, a chimera of a CMV enhancer, a chicken $\beta$-actin promoter and a rabbit $\beta$-globulin splicing site was shown to induce strong expression of genes in several tissues [79-81]. Although different promoters have been used in the design of flavivirus candidate DNA vaccines, the effect of different promoters on immunogenicity and efficacy has not been investigated [82]. However, the choice of promoters has been shown to affect immunogenicity of DNA vaccines against human immunodeficiency virus type 1 , human hepatitis B virus, and herpes simplex virus type 1 [83-85], and therefore should be taken into account when designing candidate vaccines.

5.1.2. Polyadenylation. Polyadenylation (addition of a polyA tail) of eukaryotic mRNA has several functions: (i) it aids the export of the mRNA from the nucleus, (ii) it protects the molecule from enzymatic degradation in the cytoplasm, (iii) it directs termination of transcription, and (iv) enhances translation, although poly $(\mathrm{A})$ is not necessary for translation of all mRNAs. In principle, polyadenylation occurs in three 


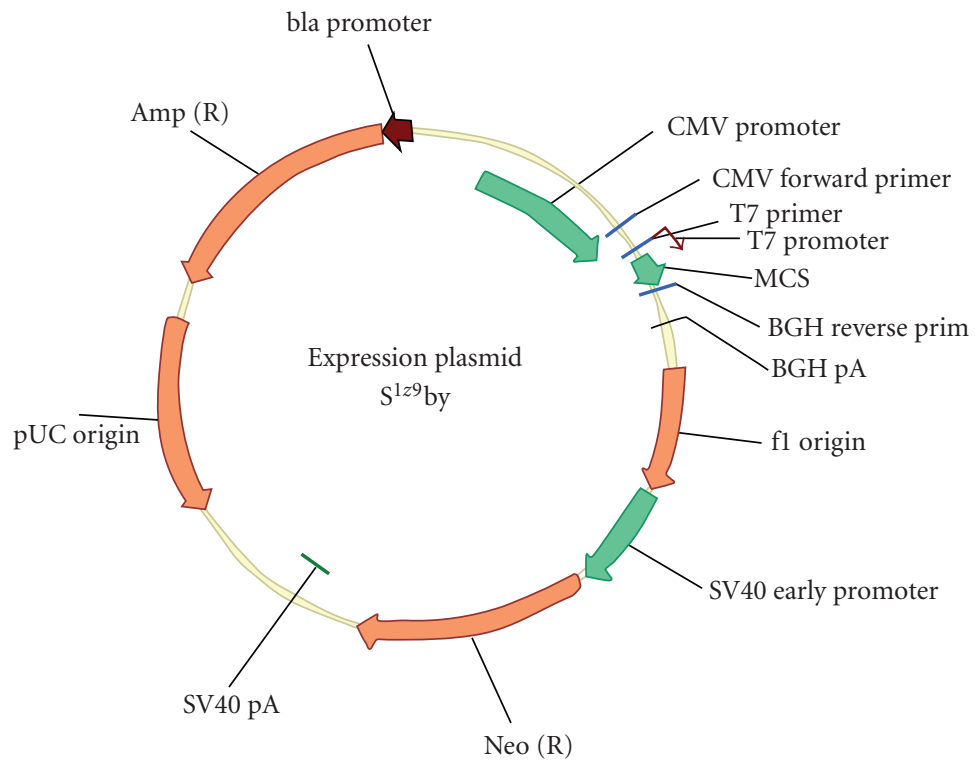

(a)

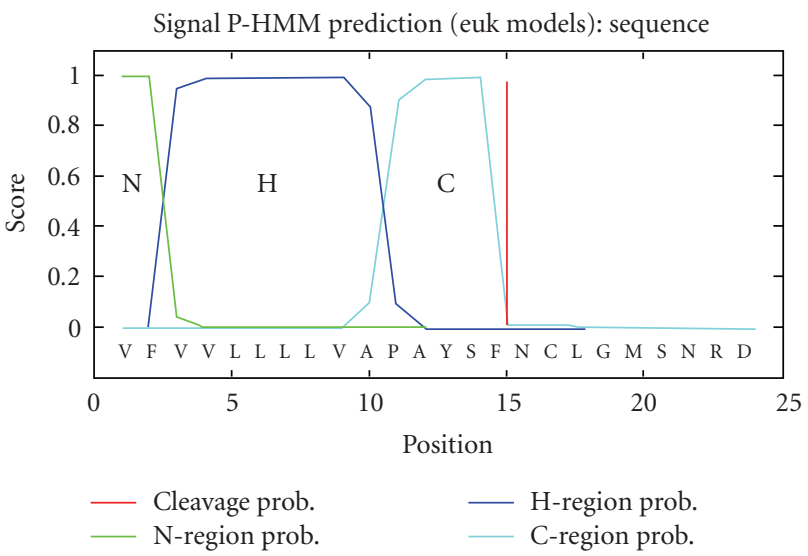

(b)

FIGURE 4: (a) A basic expression plasmid showing the CMV promoter, multiple cloning sites (MCS) and a BGH polyadenylation site, (b) Predicted signal peptide sequence for the WNV E protein. The signal peptide probability is determined by the positive polarity of the nregion, the hydrophobicity of the h-region and the uncharged amino acids occupying positions -1 and -3 in the c-region. The cleavage site is located in the c-region and is determined by the physicochemical characteristics and length of the n- and h-regions.

stages: polyadenylation site choice, cleavage of the premRNA, and addition of the poly(A) tail to the newly formed $3^{\prime}$-end [86]. The first step, polyadenylation site choice, can be defined as the preparation of the pre-mRNA to allow efficient and accurate cleavage [87]. Any mutation of the premRNA sequence elements involved in polyadenylation site choice may result in the inefficient polyadenylation of the pre-mRNA, limited nuclear export and decreased translation of the protein $[86,88,89]$. Therefore, polyadenylation site choice is an important first step in polyadenylation and is essential for optimal gene expression. The poly $(\mathrm{A})$ site of SV40 is highly efficient and frequently used as a late polyadenylation signal in many DNA plasmids. It contains efficiency elements both upstream and downstream of the AAUAAA region, and the downstream region contains three defined elements, two U-rich elements and one G-rich element, instead of the single U- or GU-rich element found in most polyadenylation signals [90]. The bovine growth hormone polyadenylation signal $(\mathrm{BGH})$ is another highly efficient and frequently used poly(A) signal in DNA vaccines. It is known that the $\mathrm{BGH}$ poly(A) pre-mRNA forms an extensive hairpin loop secondary structure at the $3^{\prime}$-UTR [91], possibly explaining the more efficient polyadenylation sequence. However, although both SV40 and BGH poly(A) signals have been shown to be highly efficient, depending on the background of the constructs used, they may negatively influence plasmid stability. The issue of promoter and poly(A) signal becomes particularly important when designing DNA vaccines. Inefficient nuclear delivery of plasmid DNA remains a major bottleneck in DNA vaccination [92], 
which may be increased by addition of a nuclear localization signal [93]. However, nuclease degradation of plasmid DNA after administration and during trafficking to the cell nucleus represents one of the main reasons of this inefficiency [94]. In this respect it has been shown that there is a correlation between the number of purine-rich regions in the $\operatorname{poly}(\mathrm{A})$ site and the susceptibility of the plasmid to nuclease degradation $[95,96]$. This indicates the importance of this region in conferring plasmid stability in addition to determining efficiency of post-transcriptional modification [95]. BGH has been shown to have the highest frequency of purine-rich regions compared to the SV40 poly(A) sequence and hence renders plasmids more susceptibility to degradation. Consistently, modification of the poly (A) site was shown to increase plasmid stability, although it negatively affected protein expression levels [95]. Taken together, plasmid resistance should be taken into account during DNA vaccine design and more efforts should be deployed to understand how rational modification of the poly(A) signal sequence may increase plasmid stability while maintaining the same levels of protein expression.

\subsection{Translational Regulator}

5.2.1. Codon Usage. It is generally appreciated that not all codons within a synonymous codon family are used at the same frequency, a phenomenon called "codon usage bias". Optimal codons are determined by high concentrations of particular transfer RNAs (tRNAs) and strong codonanticodon interactions [97, 98]. In general, closely related organisms use similar codons compared to taxonomically distant organisms [99-101]. In addition to the codon usage bias between different organisms, there are substantial differences between genes of the same organism [102, 103]. Certain codons are preferentially used in highly expressed genes [98], while use of rare codons may represent a suppressive mechanism of gene expression under inappropriate conditions. Codon usage influences translation initiation [104, 105], protein folding [106], and consequently protein expression levels. Therefore, codon usage adaptation of the target gene to those of the expression host is one way to enhance translational efficiency. Methods for optimising genes for high expression in prokaryotes, yeast, plants, and mammalian cells are becoming increasingly sophisticated and well-established in the field of vaccinology (Table 2). One measure of codon quality is the Codon Adaptation Index (CAI), a measure for the relative adaptiveness of the codon usage of a gene towards the codon usage of highly expressed genes. The index uses a reference set of highly expressed genes from a species to assess the relative merits of each codon, and a score for a gene is calculated from the frequency of use of all codons in that gene [107]. Optimizing codon usage has been shown to increase immunogenicity of candidate vaccines against both viruses and bacteria [108-114]. The increased immunogenicity is the result of improved protein transcription and translation rate, which leads to stimulation of stronger antibody and $\mathrm{T}$ cell responses. In addition, the optimized GC content contributes to a better induction of $\mathrm{T}$ cell responses through the TLR-9 pathway. Several programs are now available to analyse and adapt codon usage of a transgene to that of the host (Table 2).

5.2.2. Kozak and Leader Sequences. Sequences surrounding the start codon (AUG) within the mRNA, the so-called kozak sequences, influence the quality and quantity of the synthesized protein. The optimal context for initiation of translation in mammals is GCCRCCAUGG [115]. Optimal kozak sequences contain a high frequency of $\mathrm{A}$ at the -3 position and $\mathrm{G}$ at positions $-9,-6$, and +4 , and $\mathrm{A}$ or $\mathrm{C}$ are predominantly found at positions $-5,-4,-2$, and $-1[82$, 116]. Although it is recommended to provide viral genes with a kozak sequence, most DNA and vectored vaccines have not included this sequence in their cloning strategy. Prokaryotic genes possess an analogue of the kozak sequences, the ShineDalgarno (SD). Analysis of several E-coli genes indicates that SD sequences are present in virtually all genes [115]. Therefore, expression of genes in prokaryotic and eukaryotic systems may benefit from the insertion of respectively an SD and kozak sequence around the translation initiation codon.

Leader sequences encode signal peptides that play an important role in targeting secretory and membrane proteins in both prokaryotes and eukaryotes to the right compartment. Leader sequences are usually found at the N-terminal side of proteins, although they may also be located within a protein or at its C-terminal end [117]. Signal peptides are divided into three different regions: N-terminal $(\mathrm{n})$, hydrophobic (h), and cleavage (c) (Figure 4(b)). The hregion, which is the most essential part responsible for targeting and membrane insertion, comprises 6-15 amino acid residues. The c-region consists of small uncharged residues at positions -3 and -1 , which determines the site and probability of signal cleavage. Cleavage is more likely to occur when an amino acid with a short side-chain is present at the -1 position and no charged amino acids are present at the -3 position (reviewed in [118]). In addition, the amino acid composition of the n-region as well as the length of the h-region may affect cleavage probability [118]. The choice of the leader sequence may also influence the behaviour of proteins as type I or type II as well as the rate of protein folding within the cell. In this regard, it is interesting to note that the codon usage of signal peptides plays an important role in correct folding of proteins $[119,120]$. The use of signal sequences have been shown to affect vaccine immunogenicity and is therefore an important parameter in rational design of vaccines [121-124]. In this respect, signal peptide can have an "early" or "delayed" effect on protein maturation and secretion in that it can either cleave the signal peptide soon after translocation in the ER or delay its cleavage. It is thus of paramount importance to use custom designed vectors that carry the gene of interest for candidate DNA or subunit vaccines and with the use of bioinformatic tools determine the presence and potency of kozak and leader sequences.

\section{Flavivirus DNA and Vectored Vaccines}

Plasmids have been studied as potential candidate vaccines against several pathogens. Immunogenicity of inactivated, subunit, or vectored vaccines may be compromised in areas 
where several flaviviruses cocirculate due to interference of pre-existing crossreactive antibodies with the vaccine. DNA vaccines may therefore represent an attractive alternative for use in flavivirus endemic areas, since these are not sensitive to neutralization by flavivirus cross-reacting antibodies. However, most DNA vaccine candidates have not proven sufficiently immunogenic, although many have provided protection against disease and death in animal models [125, 126]. During virus replication, $\mathrm{prM}$ is essential for protection of the $\mathrm{E}$ protein against denaturation due to low $\mathrm{pH}$ and some believe it is crucial for correct folding of the $\mathrm{E}$ protein. Consequently, most candidate DNA vaccines encode the complete prM and $\mathrm{E}$ genes of flaviviruses. It is difficult to explain why certain vaccines proved superior to others, since different vaccines were constructed using different plasmids. Comparison of different JEV DNA vaccines revealed differences in kozak sequences surrounding the start codon [82], and differences between signal peptides of the prM. These differences have been proposed to affect the immunogenicity of the different candidate vaccines [82]. The major difference between the different signal peptide sequences are the length and composition of the $\mathrm{n}$-region. Signal peptides with a short n-region and with no positively charged amino acids may promote a type I orientation, which may affect processing efficiency and topology of the expressed prM and E proteins, and consequently immunogenicity $[127,128]$. The prediction of optimal signal peptides and use of codon optimization programs have been exploited in the development of WNV candidate vaccines, which proved to be effective in animal models and in humans $[72,129,130]$. This is the first flavivirus DNA vaccine to reach phase I clinical trials, showing promising safety and immunogenicity results [130]. The ability of such vaccines to induce neutralizing antibodies can be explained by the formation of virus-like particles with morphology similar to virus particles. The choice of complete versus truncated $\mathrm{E}$ proteins may also determine whether proteins are secreted or will remain membraneanchored and thus determine vaccine immunogenicity [131, 132]. Although DNA vaccines have not been shown to be very immunogenic, proof-of-principle for DNA vaccines has been validated with a number of flavivirus vaccine candidates in a variety of animal models. The concept of DNA vaccines as a generic flavivirus vaccine platform, especially in endemic areas, still remains viable and attractive. Many strategies are being explored to enhance the immunogenicity of DNA vaccines. The easiest and most straightforward approach that can be quickly transitioned to a clinical trial setting is vaccine delivery by a needle-free jet injector [133]. This approach has shown much potential and is the first and most forward way to enhance immunogenicity of DNA vaccines. Other approaches include the co-expression of cytokines $[134,135]$ or inclusion of sequences that enhance MHC class I and II antigen presentation [136-138]. Another promising DNA vaccine was recently described based on a single-round infectious particle system [139], which resulted in enhanced immunogenicity and efficacy against WNV.

Several viral vectors have been developed and evaluated as candidate vaccines against flaviviruses, includ- ing poxviruses [140-143], adenoviruses [144-146], measles virus [147], alphavirus [148-150], and vesicular stomatitis virus [151]. Modified Vaccina virus Ankara (MVA) is an orthopox virus vaccine vector of particular interest. MVA has been shown to be immunogenic and safe, even in severely immunocompromised animals [152]. The safety profile of MVA can be explained by the fact that the virus establishes only one round of replication, a property that is stably maintained over several passages. Furthermore, MVA and other viral vectors like the complex adenovirus (CAdVax), can harbour multiple genes, rendering them more suitable candidates for developing pan-flavivirus vaccines [153]. A variety of MVA promoters such as PmH5, P7.5, P11K, Psyn, PsynII, and Pk1L have been used for regulation of gene expression. Optimization of target DNA sequences and use of strong but not overexpressing promoter systems have been applied in the development of several MVA vaccine candidates. Viral vectors expressing $\mathrm{prM}$ and $\mathrm{E}$, $\mathrm{E}$ alone or DIII have all been shown to be effective in animal models [141, 144-146, 151, 154, 155]. Most vectored vaccines developed against flaviviruses were not optimized for polyadenylation, codon and promoter usage, providing a partial explanation for the often moderate immunogenicity observed in many cases. Similar to the immunogenicity of DNA vaccines, that of vectored vaccines can be improved by the careful choice and reconfiguration of promoters $[62,66$, 156], optimizing gene codon usage, inclusion of a consensus Kozak sequence and this all by exploiting the power of bioinformatics (Table 2).

Another promising approach for vectored vaccines is the chimeric vaccines developed using the YFV-17D backbone. Chimeric WNV candidate vaccines based on a related flavivirus vector, the YFV vaccine strain $17 \mathrm{D}$, are among the most promising vectored WNV vaccine candidates to date [157]. A vaccine based on this technology is now licensed for use in horses [158] and a similar one has undergone phase I and phase II clinical trials in humans. These chimeric vaccines exploit the safety record of the yellow fever virus vaccine strain 17D in healthy individuals, and the immunogenicity of this vector that has already been shown in experimental animals and horses as well as for a vectored vaccine against other flaviviruses, such as JEV and DENV [159-161].

\section{Concluding Remarks}

Despite numerous and continuous efforts to develop safe and effective vaccines against flaviviruses causing disease of major medical importance, there are still areas of vaccine research that need to be explored in this respect. The traditional trialand-error approach that has dominated the field of flavivirus vaccine development until today may benefit from recent advances in biotechnology and bioinformatics allowing for a more rational approach in vaccine design. The steps that should be taken to optimally exploit bioinformatics in the rational design of vaccines are shown in Figure 2.

Minimalistic approaches using certain genes or even parts thereof associated with high immunogenicity might replace whole virus-based candidate vaccines. There are several advantages in using subunit over whole virus 
vaccines. A notorious example from the flavivirus field is the immune enhancement theory that is frequently stated to explain the pathogenesis of severe DENV infections (ADE, see above). In light of this hypothesis, an ideal DENV vaccine should elicit strong antibody responses to type specific and not to cross-reactive epitopes. In this regard, the DNA and vectored vaccines tested till now did not induce better immune responses than tetravalent live-attenuated vaccines. Taking advantage of, for instance, the optimization of gene and protein expression and development of safe and potent adjuvants, seems to be imperative in the rational design of DENV vaccines. Finally, bioinformatics should play a prominent role in the process of gene optimization as well as the downstream processes of testing and selection.

Considering the advantages and disadvantages of inactivated, live-attenuated, subunit, and DNA vaccines, vectored vaccines should be considered among the most promising ones. The advantage of vectored vaccines over the others is that long-lived $\mathrm{B}$ and $\mathrm{T}$ cell responses may be induced. Furthermore, vectored vaccines based on YFV, MVA, or Adenovirus have a well-established safety record. Still, the immunogenicity and efficacy of vectored vaccines should be improved by using the knowledge and tools acquired from the DNA vaccine field. To this end, bioinformatic tools routinely used for design of DNA vaccines should also be used for careful design of synthetic genes for optimal protein expression taking the genetic background of the vector and host into account. However, bioinformatics is not systematically used to guide the rational development of safer vaccines. Several tools are available that can be used separately to eliminate for instance allergenic, immunosuppressive, oncogenic, or DNA binding sequences from the target protein. However, there is a need for integration of these tools into a software program that will allow a more rational design of safe and effective vaccines.

\section{References}

[1] M. W. Gaunt, A. A. Sall, X. de Lamballerie, A. K. I. Falconar, T. I. Dzhivanian, and E. A. Gould, "Phylogenetic relationships of flaviviruses correlate with their epidemiology, disease association and biogeography," Journal of General Virology, vol. 82, part 8, pp. 1867-1876, 2001.

[2] G. Kuno, G.-J. J. Chang, K. R. Tsuchiya, N. Karabatsos, and C. B. Cropp, "Phylogeny of the genus Flavivirus," Journal of Virology, vol. 72, no. 1, pp. 73-83, 1998.

[3] A. Oya and I. Kurane, "Japanese encephalitis for a reference to international travelers," Journal of Travel Medicine, vol. 14, no. 4, pp. 259-268, 2007.

[4] B. J. Blitvich, "Transmission dynamics and changing epidemiology of West Nile virus," Animal Health Research Reviews, vol. 9, no. 1, pp. 71-86, 2008.

[5] S. B. Halstead, "Dengue," The Lancet, vol. 370, no. 9599, pp. 1644-1652, 2007.

[6] E. Gould and T. Solomon, "Pathogenic flaviviruses," The Lancet, vol. 371, no. 9611, pp. 500-509, 2008.

[7] B. D. Lindenbach and C. M. Rice, "Molecular biology of flaviviruses," Advances in Virus Research, vol. 59, pp. 23-61, 2003.
[8] W. D. Crill and G.-J. J. Chang, "Localization and characterization of flavivirus envelope glycoprotein cross-reactive epitopes," Journal of Virology, vol. 78, no. 24, pp. 1397513986, 2004.

[9] J. T. Roehrig, R. A. Bolin, and R. G. Kelly, "Monoclonal antibody mapping of the envelope glycoprotein of the dengue 2 virus, Jamaica," Virology, vol. 246, no. 2, pp. 317-328, 1998.

[10] M. S. Diamond, T. C. Pierson, and D. H. Fremont, "The structural immunology of antibody protection against West Nile virus," Immunological Reviews, vol. 225, no. 1, pp. 212225, 2008.

[11] T. Oliphant, G. E. Nybakken, M. Engle, et al., "Antibody recognition and neutralization determinants on domains I and II of West Nile virus envelope protein," Journal of Virology, vol. 80, no. 24, pp. 12149-12159, 2006.

[12] D. E. Volk, D. W. C. Beasley, D. A. Kallick, M. R. Holbrook, A. D. T. Barrett, and D. G. Gorenstein, "Solution structure and antibody binding studies of the envelope protein domain III from the New York strain of West Nile virus," The Journal of Biological Chemistry, vol. 279, no. 37, pp. 38755-38761, 2004.

[13] D. W. C. Beasley and A. D. T. Barrett, "Identification of neutralizing epitopes within structural domain III of the West Nile virus envelope protein," Journal of Virology, vol. 76, no. 24, pp. 13097-13100, 2002.

[14] T. C. Pierson, Q. Xu, S. Nelson, et al., "The stoichiometry of antibody-mediated neutralization and enhancement of West Nile virus infection," Cell Host and Microbe, vol. 1, no. 2, pp. 135-145, 2007.

[15] T. Oliphant, M. Engle, G. E. Nybakken, et al., "Development of a humanized monoclonal antibody with therapeutic potential against West Nile virus," Nature Medicine, vol. 11, no. 5, pp. 522-530, 2005.

[16] M. S. Diamond, E. M. Sitati, L. D. Friend, S. Higgs, B. Shrestha, and M. Engle, "A critical role for induced IgM in the protection against West Nile virus infection," Journal of Experimental Medicine, vol. 198, no. 12, pp. 1853-1862, 2003.

[17] B. Shrestha and M. S. Diamond, "Role of CD8 ${ }^{+}$T cells in control of West Nile virus infection," Journal of Virology, vol. 78, no. 15, pp. 8312-8321, 2004.

[18] J. D. Brien, J. L. Uhrlaub, and J. Nikolich-Zugich, "West Nile virus-specific CD4 $\mathrm{T}$ cells exhibit direct antiviral cytokine secretion and cytotoxicity and are sufficient for antiviral protection," Journal of Immunology, vol. 181, no. 12, pp. 8568-8575, 2008.

[19] L. E. Yauch, R. M. Zellweger, M. F. Kotturi, et al., "A protective role for dengue virus-specific $\mathrm{CD}^{+} \mathrm{T}$ cells," Journal of Immunology, vol. 182, no. 8, pp. 4865-4873, 2009.

[20] D. J. Gubler, "Dengue and dengue hemorrhagic fever," Clinical Microbiology Reviews, vol. 11, no. 3, pp. 480-496, 1998.

[21] G. P. Kouri, M. G. Guzman, J. R. Bravo, and C. Triana, "Dengue haemorrhagic fever/dengue shock syndrome: lessons from the Cuban epidemic, 1981," Bulletin of the World Health Organization, vol. 67, no. 4, pp. 375-380, 1989.

[22] E. E. Ooi, K. T. Goh, and D. J. Gubler, "Dengue prevention and 35 years of vector control in Singapore," Emerging Infectious Diseases, vol. 12, no. 6, pp. 887-893, 2006.

[23] M. Theiler and H. H. Smith, "The use of yellow fever virus modified by in vitro cultivation for human immunization," The Journal of Experimental Medicine, vol. 65, no. 6, pp. 787800, 1937.

[24] V. Brusic, J. T. August, and N. Petrovsky, "Information technologies for vaccine research," Expert Review of Vaccines, vol. 4, no. 3, pp. 407-417, 2005. 
[25] K. H. Eckels and R. Putnak, "Formalin-inactivated whole virus and recombinant subunit flavivirus vaccines," Advances in Virus Research, vol. 61, pp. 395-418, 2003.

[26] M. B. Appaiahgari and S. Vrati, "Immunogenicity and protective efficacy in mice of a formaldehyde-inactivated Indian strain of Japanese encephalitis virus grown in Vero cells," Vaccine, vol. 22, no. 27-28, pp. 3669-3675, 2004.

[27] K. Sugawara, K. Nishiyama, Y. Ishikawa, et al., "Development of vero cell-derived inactivated Japanese encephalitis vaccine," Biologicals, vol. 30, no. 4, pp. 303-314, 2002.

[28] A. Wilder-Smith and D. O. Freedman, "Japanese encephalitis: is there a need for a novel vaccine?" Expert Review of Vaccines, vol. 8, no. 8, pp. 969-972, 2009.

[29] A. M. Plesner, "Allergic reactions to Japanese encephalitis vaccine," Immunology and Allergy Clinics of North America, vol. 23, no. 4, pp. 665-697, 2003.

[30] R. L. de Swart, B. G. van den Hoogen, T. Kuiken, et al., "Immunization of macaques with formalin-inactivated human metapneumovirus induces hypersensitivity to hMPV infection," Vaccine, vol. 25, no. 51, pp. 8518-8528, 2007.

[31] R. L. De Swart, T. Kuiken, H. H. Timmerman, et al., "Immunization of macaques with formalin-inactivated respiratory syncytial virus (RSV) induces interleukin-13-associated hypersensitivity to subsequent RSV infection," Journal of Virology, vol. 76, no. 22, pp. 11561-11569, 2002.

[32] B. E. Martina, P. Koraka, P. van den Doel, G. van Amerongen, G. F. Rimmelzwaan, and A. D. M. E. Osterhaus, "Immunization with West Nile virus envelope domain III protects mice against lethal infection with homologous and heterologous virus," Vaccine, vol. 26, no. 2, pp. 153-157, 2008.

[33] J.-H. J. Chu, C.-C. S. Chiang, and M.-L. Ng, "Immunization of flavivirus West Nile recombinant envelope domain III protein induced specific immune response and protection against West Nile virus infection," Journal of Immunology, vol. 178, no. 5, pp. 2699-2705, 2007.

[34] W. Zhang, X. Du, G. Zhao, et al., "Levamisole is a potential facilitator for the activation of Th1 responses of the subunit HBV vaccination," Vaccine, vol. 27, no. 36, pp. 4938-4946, 2009.

[35] C. Stahl-Hennig, M. Eisenblätter, E. Jasny, et al., "Synthetic double-stranded RNAs are adjuvants for the induction of t helper 1 and humoral immune responses to human papillomavirus in rhesus macaques," PLoS Pathogens, vol. 5, no. 4, Article ID e1000373, 2009.

[36] Y. F. Lau, L.-H. Tang, and E.-E. Ooi, "A TLR3 ligand that exhibits potent inhibition of influenza virus replication and has strong adjuvant activity has the potential for dual applications in an influenza pandemic," Vaccine, vol. 27, no. 9, pp. 1354-1364, 2009.

[37] K. Gupta and C. Cooper, "A review of the role of CpG oligodeoxynucleotides as toll-like receptor 9 agonists in prophylactic and therapeutic vaccine development in infectious diseases," Drugs in R and D, vol. 9, no. 3, pp. 137-145, 2008.

[38] D. Higgins, J. D. Marshall, P. Traquina, G. Van Nest, and B. D. Livingston, "Immunostimulatory DNA as a vaccine adjuvant," Expert Review of Vaccines, vol. 6, no. 5, pp. 747759, 2007.

[39] B. S. Park, D. H. Song, H. M. Kim, B. S. Choi, H. Lee, and J. O. Lee, "The structural basis of lipopolysaccharide recognition by the TLR4-MD-2 complex," Nature, vol. 458, no. 7242, pp. 1191-1195, 2009.

[40] J. N. Leonard, J. K. Bell, and D. M. Segal, "Predicting Tolllike receptor structures and characterizing ligand binding," Methods in Molecular Biology, vol. 517, pp. 55-67, 2009.
[41] T. P. Monie, N. J. Gay, and M. Gangloff, "Bioinformatic analysis of Toll-like receptor sequences and structures," Methods in Molecular Biology, vol. 517, pp. 69-79, 2009.

[42] W. F. McDonald, J. W. Huleatt, H. G. Foellmer, et al., "A West Nile virus recombinant protein vaccine that coactivates innate and adaptive immunity," Journal of Infectious Diseases, vol. 195, no. 11, pp. 1607-1617, 2007.

[43] S. J. Seligman and E. A. Gould, "Live flavivirus vaccines: reasons for caution," The Lancet, vol. 363, no. 9426, pp. 20732075, 2004.

[44] P. Koraka, S. Benton, G. van Amerongen, K. J. Stittelaar, and A. D. M. E. Osterhaus, "Efficacy of a live attenuated tetravalent candidate dengue vaccine in naive and previously infected cynomolgus macaques," Vaccine, vol. 25, no. 29, pp. 5409-5416, 2007.

[45] W. Sun, A. Nisalak, M. Gettayacamin, et al., "Protection of rhesus monkeys against dengue virus challenge after tetravalent live attenuated dengue virus vaccination," Journal of Infectious Diseases, vol. 193, no. 12, pp. 1658-1665, 2006.

[46] W. Sun, D. Cunningham, S. S. Wasserman, et al., "Phase 2 clinical trial of three formulations of tetravalent liveattenuated dengue vaccine in flavivirus-naive adults," Human Vaccines, vol. 5, no. 1, pp. 33-40, 2009.

[47] S. Simasathien, S. J. Thomas, V. Watanaveeradej, et al., "Safety and immunogenicity of a tetravalent live-attenuated dengue vaccine in flavivirus naive children," American Journal of Tropical Medicine and Hygiene, vol. 78, no. 3, pp. 426433, 2008.

[48] S. Kitchener, M. Nissen, P. Nasveld, et al., "Immunogenicity and safety of two live-attenuated tetravalent dengue vaccine formulations in healthy Australian adults," Vaccine, vol. 24, no. 9, pp. 1238-1241, 2006.

[49] D. E. Alvarez, A. L. De Lella Ezcurra, S. Fucito, and A. V. Gamarnik, "Role of RNA structures present at the 3'UTR of dengue virus on translation, RNA synthesis, and viral replication," Virology, vol. 339, no. 2, pp. 200-212, 2005.

[50] V. Proutski, M. W. Gaunt, E. A. Gould, and E. C. Holmes, "Secondary structure of the 3 ' -untranslated region of yellow fever virus: implications for virulence, attenuation and vaccine development," Journal of General Virology, vol. 78, part 7, pp. 1543-1549, 1997.

[51] V. Proutski, E. A. Gould, and E. C. Holmes, "Secondary structure of the $3^{\prime}$ untranslated region of flaviviruses: similarities and differences," Nucleic Acids Research, vol. 25, no. 6, pp. 1194-1202, 1997.

[52] V. Proutski, T. S. Gritsun, E. A. Gould, and E. C. Holmes, "Biological consequences of deletions within the 3 ' untranslated region of flaviviruses may be due to rearrangements of RNA secondary structure," Virus Research, vol. 64, no. 2, pp. 107-123, 1999.

[53] J. E. Blaney Jr., D. H. Johnson, G. G. Manipon, et al., "Genetic basis of attenuation of dengue virus type 4 small plaque mutants with restricted replication in suckling mice and in SCID mice transplanted with human liver cells," Virology, vol. 300, no. 1, pp. 125-139, 2002.

[54] A. P. Durbin, R. A. Karron, W. Sun, et al., "Attenuation and immunogenicity in humans of a live dengue virus type-4 vaccine candidate with a 30 nucleotide deletion in its $3^{\prime}$ untranslated region," American Journal of Tropical Medicine and Hygiene, vol. 65, no. 5, pp. 405-413, 2001.

[55] S. S. Whitehead, B. Falgout, K. A. Hanley, J. E. Blaney Jr., L. Markoff, and B. R. Murphy, "A live, attenuated dengue virus 
type 1 vaccine candidate with a 30 -nucleotide deletion in the $3^{\prime}$ untranslated region is highly attenuated and immunogenic in monkeys," Journal of Virology, vol. 77, no. 2, pp. 16531657, 2003.

[56] J. E. Blaney Jr., C. T. Hanson, C. Y. Firestone, K. A. Hanley, B. R. Murphy, and S. S. Whitehead, "Genetically modified, live attenuated dengue virus type 3 vaccine candidates," American Journal of Tropical Medicine and Hygiene, vol. 71, no. 6, pp. 811-821, 2004.

[57] J. E. Blaney Jr., C. T. Hanson, K. A. Hanley, B. R. Murphy, and S. S. Whitehead, "Vaccine candidates derived from a novel infectious cDNA clone of an American genotype dengue virus type 2," BMC Infectious Diseases, vol. 4, no. 4, article $39,2004$.

[58] J. E. Blaney Jr., N. S. Sathe, L. Goddard, et al., "Dengue virus type 3 vaccine candidates generated by introduction of deletions in the $3^{\prime}$ untranslated region $\left(3^{\prime}\right.$-UTR) or by exchange of the DENV-3 $3^{\prime}$-UTR with that of DENV-4," Vaccine, vol. 26, no. 6, pp. 817-828, 2008.

[59] C. S. Hahn, J. M. Dalrymple, J. H. Strauss, and C. M. Rice, "Comparison of the virulent Asibi strain of yellow fever virus with the 17D vaccine strain derived from it," Proceedings of the National Academy of Sciences of the United States of America, vol. 84, no. 7, pp. 2019-2023, 1987.

[60] Z.-L. Xu, H. Mizuguchi, A. Ishii-Watabe, E. Uchida, T. Mayumi, and T. Hayakawa, "Optimization of transcriptional regulatory elements for constructing plasmid vectors," Gene, vol. 272, no. 1-2, pp. 149-156, 2001.

[61] C. Beck, H. Uramoto, J. Boren, and L. M. Akyurek, "Tissuespecific targeting for cardiovascular gene transfer. Potential vectors and future challenges," Current Gene Therapy, vol. 4, no. 4, pp. 457-467, 2004.

[62] A. R. Brooks, R. N. Harkins, P. Wang, H. S. Qian, P. Liu, and G. M. Rubanyi, "Transcriptional silencing is associated with extensive methylation of the CMV promoter following adenoviral gene delivery to muscle," Journal of Gene Medicine, vol. 6, no. 4, pp. 395-404, 2004.

[63] L. Qin, Y. Ding, D. R. Pahud, E. Chang, M. J. Imperiale, and J. S. Bromberg, "Promoter attenuation in gene therapy: interferon- $\gamma$ and tumor necrosis factor- $\alpha$ inhibit transgene expression," Human Gene Therapy, vol. 8, no. 17, pp. 20192029, 1997.

[64] M. Al-Dosari, G. Zhang, J. E. Knapp, and D. Liu, "Evaluation of viral and mammalian promoters for driving transgene expression in mouse liver," Biochemical and Biophysical Research Communications, vol. 339, no. 2, pp. 673-678, 2006.

[65] F. Takeshita, K. Takase, M. Tozuka, et al., "Muscle creatine kinase/SV40 hybrid promoter for muscle-targeted long-term transgene expression," International Journal of Molecular Medicine, vol. 19, no. 2, pp. 309-315, 2007.

[66] M. Mori-Uchino, T. Takeuchi, I. Murakami, et al., "Enhanced transgene expression in the mouse skeletal muscle infected by the adeno-associated viral vector with the human elongation factor $1 \alpha$ promoter and a human chromatin insulator," Journal of Gene Medicine, vol. 11, no. 7, pp. 598-604, 2009.

[67] S. Hong, D. Y. Hwang, S. Yoon, et al., "Functional analysis of various promoters in lentiviral vectors at different stages of in vitro differentiation of mouse embryonic stem cells," Molecular Therapy, vol. 15, no. 9, pp. 1630-1639, 2007.

[68] T. Vanniasinkam, S. T. Reddy, and H. C. J. Ertl, "DNA immunization using a non-viral promoter," Virology, vol. 344, no. 2, pp. 412-420, 2006.

[69] J.-S. Song, "Activity of the human telomerase catalytic subunit (hTERT) gene promoter could be increased by the
SV40 enhancer," Bioscience, Biotechnology and Biochemistry, vol. 68, no. 8, pp. 1634-1639, 2004.

[70] M. Yago, R. Ohki, S. Hatakeyama, T. Fujita, and F. Ishikawa, "Variant forms of upstream stimulatory factors (USFs) control the promoter activity of hTERT, the human gene encoding the catalytic subunit of telomerase," FEBS Letters, vol. 520, no. 1-3, pp. 40-46, 2002.

[71] I. Horikawa, P. L. Cable, C. Afshari, and J. C. Barrett, "Cloning and characterization of the promoter region of human telomerase reverse transcriptase gene," Cancer Research, vol. 59, no. 4, pp. 826-830, 1999.

[72] M. S. Ashok and P. N. Rangarajan, "Protective efficacy of a plasmid DNA encoding Japanese encephalitis virus envelope protein fused to tissue plasminogen activator signal sequences: studies in a murine intracerebral virus challenge model," Vaccine, vol. 20, no. 11-12, pp. 1563-1570, 2002.

[73] Z. S. Guo, Q. Li, D. L. Bartlett, J. Y. Yang, and B. Fang, "Gene transfer: the challenge of regulated gene expression," Trends in Molecular Medicine, vol. 14, no. 9, pp. 410-418, 2008.

[74] A. H. Lee, Y. S. Suh, J. H. Sung, S. H. Yang, and Y. C. Sung, "Comparison of various expression plasmids for the induction of immune response by DNA immunization," Molecules and Cells, vol. 7, no. 4, pp. 495-501, 1997.

[75] B. S. Chapman, R. M. Thayer, K. A. Vincent, and N. L. Haigwood, "Effect of intron A from human cytomegalovirus (Towne) immediate-early gene on heterologous expression in mammalian cells," Nucleic Acids Research, vol. 19, no. 14, pp. 3979-3986, 1991.

[76] J. Chinsangaram, C. Beard, P. W. Mason, M. K. Zellner, G. Ward, and M. J. Grubman, "Antibody response in mice inoculated with DNA expressing foot-and- mouth disease virus capsid proteins," Journal of Virology, vol. 72, no. 5, pp. 4454-4457, 1998.

[77] M. T. F. Huang and C. M. Gorman, "Intervening sequences increase efficiency of RNA 3 ' processing and accumulation of cytoplasmic RNA," Nucleic Acids Research, vol. 18, no. 4, pp. 937-947, 1990.

[78] M. T. F. Huang and C. M. Gorman, "The simian virus 40 small-t intron, present in many common expression vectors, leads to aberrant splicing," Molecular and Cellular Biology, vol. 10, no. 4, pp. 1805-1810, 1990.

[79] L.-M. You, J. Luo, A.-P. Wang, et al., "A hybrid promotercontaining vector for direct cloning and enhanced expression of PCR-amplified ORFs in mammalian cells," Molecular Biology Reports. In press.

[80] S. Garg, A. E. Oran, H. Hon, and J. Jacob, "The hybrid cytomegalovirus enhancer/chicken $\beta$-actin promoter along with woodchuck hepatitis virus posttranscriptional regulatory element enhances the protective efficacy of DNA vaccines," Journal of Immunology, vol. 173, no. 1, pp. 550$558,2004$.

[81] A. N. Alexopoulou, J. R. Couchman, and J. R. Whiteford, "The CMV early enhancer/chicken $\beta$ actin (CAG) promoter can be used to drive transgene expression during the differentiation of murine embryonic stem cells into vascular progenitors," BMC Cell Biology, vol. 9, article 2, 2008.

[82] G.-J. J. Chang, B. S. Davis, A. R. Hunt, D. A. Holmes, and G. Kuno, "Flavivirus DNA vaccines: current status and potential," Annals of the New York Academy of Sciences, vol. 951, pp. 272-285, 2001.

[83] A. P. Jathoul, J. L. Holley, and H. S. Garmory, "Efficacy of DNA vaccines expressing the type $\mathrm{F}$ botulinum toxin $\mathrm{Hc}$ fragment using different promoters," Vaccine, vol. 22, no. 2930, pp. 3942-3946, 2004. 
[84] K. Santos, C. M. P. Duke, S. M. Rodriguez-Colon, et al., "Effect of promoter strength on protein expression and immunogenicity of an HSV-1 amplicon vector encoding HIV-1 Gag," Vaccine, vol. 25, no. 9, pp. 1634-1646, 2007.

[85] S. Wang, D. J. Farfan-Arribas, S. Shen, et al., "Relative contributions of codon usage, promoter efficiency and leader sequence to the antigen expression and immunogenicity of HIV-1 Env DNA vaccine," Vaccine, vol. 24, no. 21, pp. 45314540, 2006.

[86] J. Zhao, L. Hyman, and C. Moore, "Formation of mRNA 3 ' ends in eukaryotes: mechanism, regulation, and interrelationships with other steps in mRNA synthesis," Microbiology and Molecular Biology Reviews, vol. 63, no. 2, pp. 405-445, 1999.

[87] G. M. Gilmartin and J. R. Nevins, "An ordered pathway of assembly of components required for polyadenylation site recognition and processing," Genes and Development, vol. 3, no. $12 B$, pp. 2180-2190, 1989.

[88] C. Montell, E. F. Fisher, M. H. Caruthers, and A. J. Berk, "Inhibition of RNA cleavage but not polyadenylation by a point mutation in mRNA $3^{\prime}$ consensus sequence AAUAAA," Nature, vol. 305, no. 5935, pp. 600-605, 1983.

[89] M. D. Sheets, S. C. Ogg, and M. P. Wickens, "Point mutations of AAUAAA and the poly (A) addition site: effects on the accuracy and efficiency of cleavage and polyadenylation in vitro," Nucleic Acids Research, vol. 18, no. 19, pp. 5799-5805, 1990.

[90] H. Hans and J. C. Alwine, "Functionally significant secondary structure of the simian virus 40 late polyadenylation signal," Molecular and Cellular Biology, vol. 20, no. 8, pp. 2926-2932, 2000.

[91] E. R. Gimmi, M. E. Reff, and I. C. Deckman, "Alterations in the pre-mRNA topology of the bovine growth hormone polyadenylation region decrease poly(A) site efficiency," Nucleic Acids Research, vol. 17, no. 17, pp. 6983-6998, 1989.

[92] C. M. Roth and S. Sundaram, "Engineering synthetic vectors for improved DNA delivery: insights from intracellular pathways," Annual Review of Biomedical Engineering, vol. 6, pp. 397-426, 2004.

[93] R. Schirmbeck, S. A. Konig-Merediz, P. Riedl, et al., "Priming of immune responses to hepatitis B surface antigen with minimal DNA expression constructs modified with a nuclear localization signal peptide," Journal of Molecular Medicine, vol. 79, no. 5-6, pp. 343-350, 2001.

[94] H. Pollard, G. Toumaniantz, J. L. Amos, et al., " $\mathrm{Ca}^{2+}$-sensitive cytosolic nucleases prevent efficient delivery to the nucleus of injected plasmids," Journal of Gene Medicine, vol. 3, no. 2, pp. 153-164, 2001.

[95] A. R. Azzoni, S. C. Ribeiro, G. A. Monteiro, and D. M. F. Prazeres, "The impact of polyadenylation signals on plasmid nuclease-resistance and transgene expression," Journal of Gene Medicine, vol. 9, no. 5, pp. 392-402, 2007.

[96] S. C. Ribiero, G. A. Monteiro, and D. M. Prazeres, "The role of polyadenylation signal secondary structures on the resistance of plasmid vectors to nucleases," Journal of Gene Medicine, vol. 6, no. 5, pp. 565-573, 2004.

[97] T. Ikemura, "Correlation between the abundance of Escherichia coli transfer RNAs and the occurrence of the respective codons in its protein genes," Journal of Molecular Biology, vol. 146, no. 1, pp. 1-21, 1981.

[98] J. Zhou, W. J. Liu, S. W. Peng, X. Y. Sun, and I. Frazer, "Papillomavirus capsid protein expression level depends on the match between codon usage and tRNA availability," Journal of Virology, vol. 73, no. 6, pp. 4972-4982, 1999.
[99] T. Ikemura, "Codon usage and tRNA content in unicellular and multicellular organisms," Molecular Biology and Evolution, vol. 2, no. 1, pp. 13-34, 1985.

[100] T. Ikemura, "Correlation between the abundance of yeast transfer RNAs and the occurrence of the respective codons in protein genes. Differences in synonymous codon choice patterns of yeast and Escherichia coli with reference to the abundance of isoaccepting transfer RNAs," Journal of Molecular Biology, vol. 158, no. 4, pp. 573-597, 1982.

[101] R. Grantham, C. Gautier, M. Gouy, M. Jacobzone, and R. Mercier, "Codon catalog usage is a genome strategy modulated for gene expressivity," Nucleic Acids Research, vol. 9, no. 1, pp. r43-r74, 1981.

[102] P. M. Sharp, T. M. Tuohy, and K. R. Mosurski, "Codon usage in yeast: cluster analysis clearly differentiates highly and lowly expressed genes," Nucleic Acids Research, vol. 14, no. 13, pp. 5125-5143, 1986.

[103] A. Wang, L. Ren, G. Abenes, and R. Hai, "Genome sequence divergences and functional variations in human cytomegalovirus strains," FEMS Immunology and Medical Microbiology, vol. 55, no. 1, pp. 23-33, 2009.

[104] C. M. Stenstrom and L. A. Isaksson, "Influences on translation initiation and early elongation by the messenger RNA region flanking the initiation codon at the 3 ' side," Gene, vol. 288, no. 1-2, pp. 1-8, 2002.

[105] A. C. Looman, J. Bodlaender, L. J. Comstock, et al., "Influence of the codon following the AUG initiation codon on the expression of a modified lacZ gene in Escherichia coli," EMBO Journal, vol. 6, no. 8, pp. 2489-2492, 1987.

[106] A. A. Komar, T. Lesnik, and C. Reiss, "Synonymous codon substitutions affect ribosome traffic and protein folding during in vitro translation," FEBS Letters, vol. 462, no. 3, pp. 387-391, 1999.

[107] P. M. Sharp and W. H. Li, "The codon adaptation index-a measure of directional synonymous codon usage bias, and its potential applications," Nucleic Acids Research, vol. 15, no. 3, pp. 1281-1295, 1987.

[108] L. Deml, A. Bojak, S. Steck, et al., "Multiple effects of codon usage optimization on expression and immunogenicity of DNA candidate vaccines encoding the human immunodeficiency virus type 1 Gag protein," Journal of Virology, vol. 75, no. 22, pp. 10991-11001, 2001.

[109] M. Uchijima, A. Yoshida, T. Nagata, and Y. Koide, "Optimization of codon usage of plasmid DNA vaccine is required for the effective MHC class I-restricted T cell responses against an intracellular bacterium," Journal of Immunology, vol. 161, no. 10, pp. 5594-5599, 1998.

[110] T. Nagata, M. Uchijima, A. Yoshida, M. Kawashima, and Y. Koide, "Codon optimization effect on translational efficiency of DNA vaccine in mammalian cells: analysis of plasmid DNA encoding a CTL epitope derived from microorganisms," Biochemical and Biophysical Research Communications, vol. 261, no. 2, pp. 445-451, 1999.

[111] Y.-K. Cheung, S. C.-S. Cheng, F. W.-Y. Sin, and Y. Xie, "Plasmid encoding papillomavirus type 16 (HPV16) DNA constructed with codon optimization improved the immunogenicity against HPV infection," Vaccine, vol. 23, no. 5, pp. 629-638, 2004.

[112] L. Frelin, G. Ahlen, M. Alheim, et al., "Codon optimization and mRNA amplification effectively enhances the immunogenecity of the hepatitis $\mathrm{C}$ virus nonstructural 3/4A gene," Gene Therapy, vol. 11, no. 6, pp. 522-533, 2004.

[113] F. Gao, Y. Li, J. M. Decker, et al., "Codon usage optimization of HIV type 1 subtype $\mathrm{C}$ gag, pol, env, and nef genes: in vitro 
expression and immune responses in DNA-vaccinated mice," AIDS Research and Human Retroviruses, vol. 19, no. 9, pp. 817-823, 2003.

[114] H. J. Ko, S. Y. Ko, Y. J. Kim, E. G. Lee, S.-N. Cho, and C.-Y. Kang, "Optimization of codon usage enhances the immunogenicity of a DNA vaccine encoding mycobacterial antigen Ag85B," Infection and Immunity, vol. 73, no. 9, pp. 5666-5674, 2005.

[115] M. Kozak, "Regulation of translation via mRNA structure in prokaryotes and eukaryotes," Gene, vol. 361, no. 1-2, pp. 1337, 2005

[116] D. R. Cavener and S. C. Ray, "Eukaryotic start and stop translation sites," Nucleic Acids Research, vol. 19, no. 12, pp. 3185-3192, 1991.

[117] U. Kutay, G. Ahnert-Hilger, E. Hartmann, B. Wiedenmann, and T. A. Rapoport, "Transport route for synaptobrevin via a novel pathway of insertion into the endoplasmic reticulum membrane," EMBO Journal, vol. 14, no. 2, pp. 217-223, 1995.

[118] B. Martoglio and B. Dobberstein, "Signal sequences: more than just greasy peptides," Trends in Cell Biology, vol. 8, no. 10, pp. 410-415, 1998.

[119] Y. M. Zalucki, I. R. Beacham, and M. P. Jennings, "Biased codon usage in signal peptides: a role in protein export," Trends in Microbiology, vol. 17, no. 4, pp. 146-150, 2009.

[120] M. Sakaguchi, R. Tomiyoshi, T. Kuroiwa, K. Mihara, and T. Omura, "Functions of signal and signal-anchor sequences are determined by the balance between the hydrophobic segment and the N-terminal charge," Proceedings of the National Academy of Sciences of the United States of America, vol. 89, no. 1, pp. 16-19, 1992.

[121] I. Sominskaya, E. Alekseeva, D. Skrastina, et al., "Signal sequences modulate the immunogenic performance of human hepatitis C virus E2 gene," Molecular Immunology, vol. 43, no. 12, pp. 1941-1952, 2006.

[122] Z. Li, A. Howard, C. Kelley, G. Delogu, F. Collins, and S. Morris, "Immunogenicity of DNA vaccines expressing tuberculosis proteins fused to tissue plasminogen activator signal sequences," Infection and Immunity, vol. 67, no. 9, pp. 4780-4786, 1999.

[123] M. Luo, P. Tao, J. Li, S. Zhou, D. Guo, and Z. Pan, "Immunization with plasmid DNA encoding influenza A virus nucleoprotein fused to a tissue plasminogen activator signal sequence elicits strong immune responses and protection against $\mathrm{H} 5 \mathrm{~N} 1$ challenge in mice," Journal of Virological Methods, vol. 154, no. 1-2, pp. 121-127, 2008.

[124] C. Jiang, D. M. Magee, F. D. Ivey, and R. A. Cox, "Role of signal sequence in vaccine-induced protection against experimental coccidioidomycosis," Infection and Immunity, vol. 70, no. 7, pp. 3539-3545, 2002.

[125] R. Putnak, K. Porter, and C. Schmaljohn, "DNA vaccines for flaviviruses," Advances in Virus Research, vol. 61, pp. 445-468, 2003.

[126] C. J. Wu, T. L. Li, H. W. Huang, M. H. Tao, and Y. L. Chan, "Development of an effective Japanese encephalitis virusspecific DNA vaccine," Microbes and Infection, vol. 8, no. 11, pp. 2578-2586, 2006.

[127] G.-J. J. Chang, A. R. Hunt, and B. Davis, "A single intramuscular injection of recombinant plasmid DNA induces protective immunity and prevents Japanese encephalitis in mice," Journal of Virology, vol. 74, no. 9, pp. 4244-4252, 2000.

[128] E. Konishi, M. Yamaoka, Khin-Sane-Win, I. Kurane, and P. W. Mason, "Induction of protective immunity against japanese encephalitis in mice by immunization with a plasmid encoding Japanese encephalitis virus premembrane and envelope genes," Journal of Virology, vol. 72, no. 6, pp. 4925-4930, 1998.

[129] B. S. Davis, G.-J. J. Chang, B. Cropp, et al., "West Nile virus recombinant DNA vaccine protects mouse and horse from virus challenge and expresses in vitro a noninfectious recombinant antigen that can be used in enzyme-linked immunosorbent assays," Journal of Virology, vol. 75, no. 9, pp. 4040-4047, 2001.

[130] J. E. Martin, T. C. Pierson, S. Hubka, et al., "A West Nile virus DNA vaccine induces neutralizing antibody in healthy adults during a phase 1 clinical trial," Journal of Infectious Diseases, vol. 196, no. 12, pp. 1732-1740, 2007.

[131] R. Kaur, G. Sachdeva, and S. Vrati, "Plasmid DNA immunization against Japanese encephalitis virus: immunogenicity of membrane-anchored and secretory envelope protein," Journal of Infectious Diseases, vol. 185, no. 1, pp. 1-12, 2002.

[132] K. Raviprakash, T. J. Kochel, D. Ewing, et al., "Immunogenicity of dengue virus type 1 DNA vaccines expressing truncated and full length envelope protein," Vaccine, vol. 18, no. 22, pp. 2426-2434, 2000.

[133] K. Raviprakash and K. R. Porter, "Needle-free injection of DNA vaccines: a brief overview and methodology," Methods in Molecular Medicine, vol. 127, pp. 83-89, 2006.

[134] K. Raviprakash, E. Marques, D. Ewing, et al., "Synergistic neutralizing antibody response to a dengue virus type 2 DNA vaccine by incorporation of lysosome-associated membrane protein sequences and use of plasmid expressing GM-CSF," Virology, vol. 290, no. 1, pp. 74-82, 2001.

[135] K. Bharati, M. B. Appaiahgari, and S. Vrati, "Effect of cytokine-encoding plasmid delivery on immune response to Japanese encephalitis virus DNA vaccine in mice," Microbiology and Immunology, vol. 49, no. 4, pp. 349-353, 2005.

[136] Y. Lu, K. Raviprakash, I. C. Leao, et al., "Dengue 2 PreME/LAMP chimera targeted to the MHC class II compartment elicits long-lasting neutralizing antibodies," Vaccine, vol. 21, no. 17-18, pp. 2187-2198, 2003.

[137] K. Isaji, A. Kawase, M. Matono, X. Guan, M. Nishikawa, and Y. Takakura, "Enhanced CTL response by controlled intracellular trafficking of antigen in dendritic cells following DNA vaccination," Journal of Controlled Release, vol. 135, no. 3, pp. 227-233, 2009.

[138] S. J. Kim, C. Lee, S. Y. Lee, et al., "Enhanced immunogenicity of human papillomavirus $16 \mathrm{~L} 1$ genetic vaccines fused to an ER-targeting secretory signal peptide and RANTES," Gene Therapy, vol. 10, no. 15, pp. 1268-1273, 2003.

[139] D. C. Chang, W. J. Liu, I. Anraku, et al., "Single-round infectious particles enhance immunogenicity of a DNA vaccine against West Nile virus," Nature Biotechnology, vol. 26, no. 5, pp. 571-577, 2008.

[140] J. H. Nam, H. S. Bang, H. W. Cho, and Y. H. Chung, "Different contribution of co-stimulatory molecules B7.1 and B7.2 to the immune response to recombinant modified vaccinia virus ankara vaccine expressing $\mathrm{prM} / \mathrm{E}$ proteins of Japanese encephalitis virus and two hepatitis B virus vaccines," Acta Virologica, vol. 51, no. 2, pp. 125-130, 2007.

[141] R. Men, L. Wyatt, I. Tokimatsu, et al., "Immunization of rhesus monkeys with a recombinant of modified vaccinia virus Ankara expressing a truncated envelope glycoprotein of dengue type 2 virus induced resistance to dengue type 2 virus challenge," Vaccine, vol. 18, no. 27, pp. 3113-3122, 2000.

[142] E. Konishi, I. Kurane, P. W. Mason, R. E. Shope, and F. A. Ennis, "Poxvirus-based Japanese encephalitis vaccine candidates induce JE virus-specific $\mathrm{CD} 8^{+}$cytotoxic T lymphocytes in mice," Virology, vol. 227, no. 2, pp. 353-360, 1997. 
[143] K. K. Seino, M. T. Long, E. P. J. Gibbs, et al., "Comparative efficacies of three commercially available vaccines against West Nile virus (WNV) in a short-duration challenge trial involving an equine WNV encephalitis model," Clinical and Vaccine Immunology, vol. 14, no. 11, pp. 1465-1471, 2007.

[144] K. Raviprakash, D. Wang, D. Ewing, et al., "A tetravalent dengue vaccine based on a complex adenovirus vector provides significant protection in rhesus monkeys against all four serotypes of dengue virus," Journal of Virology, vol. 82, no. 14, pp. 6927-6934, 2008.

[145] S. Khanam, N. Khanna, and S. Swaminathan, "Induction of neutralizing antibodies and $\mathrm{T}$ cell responses by dengue virus type 2 envelope domain III encoded by plasmid and adenoviral vectors," Vaccine, vol. 24, no. 42-43, pp. 65136525, 2006.

[146] M. B. Appaiahgari, M. Saini, M. Rauthan, Jyoti, and S. Vrati, "Immunization with recombinant adenovirus synthesizing the secretory form of Japanese encephalitis virus envelope protein protects adenovirus-exposed mice against lethal encephalitis," Microbes and Infection, vol. 8, no. 1, pp. 92-104, 2006.

[147] P. Despres, C. Combredet, M.-P. Frenkiel, C. Lorin, M. Brahic, and F. Tangy, "Live measles vaccine expressing the secreted form of the West Nile virus envelope glycoprotein protects against West Nile virus encephalitis," Journal of Infectious Diseases, vol. 191, no. 2, pp. 207-214, 2005.

[148] L. J. White, M. M. Parsons, A. C. Whitmore, B. M. Williams, A. De Silva, and R. E. Johnston, "An immunogenic and protective alphavirus replicon particle-based dengue vaccine overcomes maternal antibody interference in weanling mice," Journal of Virology, vol. 81, no. 19, pp. 10329-10339, 2007.

[149] M. N. Fleeton, P. Liljeström, B. J. Sheahan, and G. J. Atkins, "Recombinant Semliki Forest virus particles expressing louping ill virus antigens induce a better protective response than plasmid-based DNA vaccines or an inactivated whole particle vaccine," Journal of General Virology, vol. 81, part 3, pp. 749758,2000 .

[150] G. Colombage, R. Hall, M. Pavy, and M. Lobigs, "DNAbased and alphavirus-vectored immunisation with PrM and E proteins elicits long-lived and protective immunity against the flavivirus, Murray Valley encephalitis virus," Virology, vol. 250, no. 1, pp. 151-163, 1998.

[151] A. V. Iyer, B. Pahar, M. J. Boudreaux, et al., "Recombinant vesicular stomatitis virus-based West Nile vaccine elicits strong humoral and cellular immune responses and protects mice against lethal challenge with the virulent West Nile virus strain LSU-AR01," Vaccine, vol. 27, no. 6, pp. 893-903, 2009.

[152] K. J. Stittelaar, T. Kuiken, R. L. de Swart, et al., "Safety of modified vaccinia virus Ankara (MVA) in immunesuppressed macaques," Vaccine, vol. 19, no. 27, pp. 37003709, 2001.

[153] D. L. Swenson, D. Wang, M. Luo, et al., "Vaccine to confer to nonhuman primates complete protection against multistrain Ebola and Marburg virus infections," Clinical and Vaccine Immunology, vol. 15, no. 3, pp. 460-467, 2008.

[154] J. Schepp-Berglind, M. Luo, D. Wang, et al., "Complex adenovirus-mediated expression of West Nile Virus C, preM, $\mathrm{E}$, and NS1 proteins induces both humoral and cellular immune responses," Clinical and Vaccine Immunology, vol. 14, no. 9, pp. 1117-1126, 2007.

[155] J. H. Nam, S. L. Chae, and H. W. Cho, "Immunogenicity of a recombinant MVA and a DNA vaccine for Japanese encephalitis virus in swine," Microbiology and Immunology, vol. 46, no. 1, pp. 23-28, 2002.
[156] B. Wang, J. Li, F. H. Fu, et al., "Construction and analysis of compact muscle-specific promoters for AAV vectors," Gene Therapy, vol. 15, no. 22, pp. 1489-1499, 2008.

[157] R. A. Hall and A. A. Khromykh, "ChimeriVax-West Nile vaccine," Current Opinion in Molecular Therapeutics, vol. 9, no. 5, pp. 498-504, 2007.

[158] G. Dauphin and S. Zientara, "West Nile virus: recent trends in diagnosis and vaccine development," Vaccine, vol. 25, no. 30, pp. 5563-5576, 2007.

[159] D. W. C. Beasley, L. Li, M. T. Suderman, et al., "Protection against Japanese encephalitis virus strains representing four genotypes by passive transfer of sera raised against ChimeriVax-JE experimental vaccine," Vaccine, vol. 22, no. 27-28, pp. 3722-3726, 2004.

[160] C. E. McGee, M. G. Lewis, M. S. Claire, et al., "Recombinant chimeric virus with wild-type dengue 4 virus premembrane and envelope and virulent yellow fever virus Asibi backbone sequences is dramatically attenuated in nonhuman primates," Journal of Infectious Diseases, vol. 197, no. 5, pp. 693-697, 2008.

[161] F. Guirakhoo, K. Pugachev, J. Arroyo, et al., "Viremia and immunogenicity in nonhuman primates of a tetravalent yellow fever-dengue chimeric vaccine: genetic reconstructions, dose adjustment, and antibody responses against wild-type dengue virus isolates," Virology, vol. 298, no. 1, pp. 146-159, 2002. 

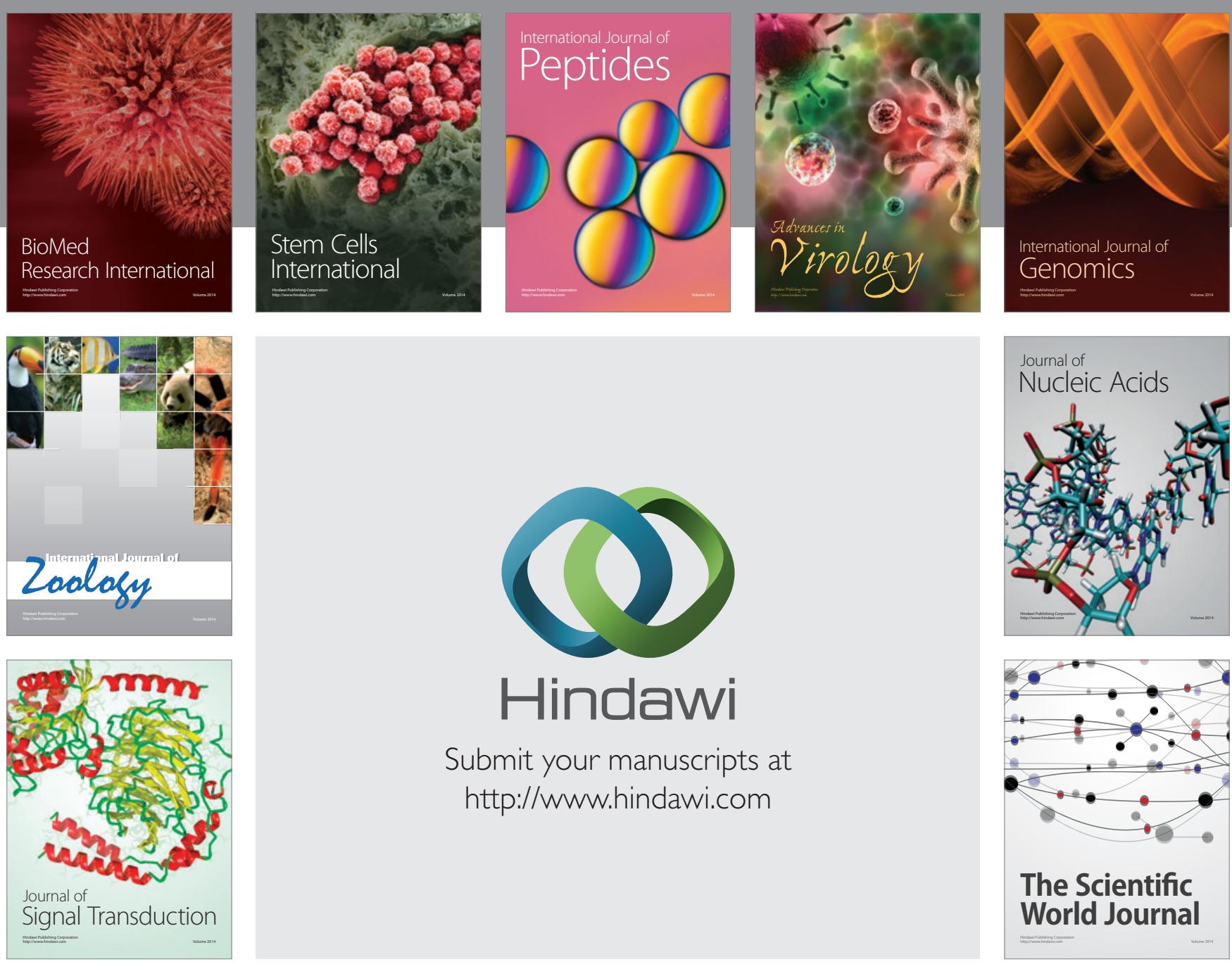

Submit your manuscripts at

http://www.hindawi.com
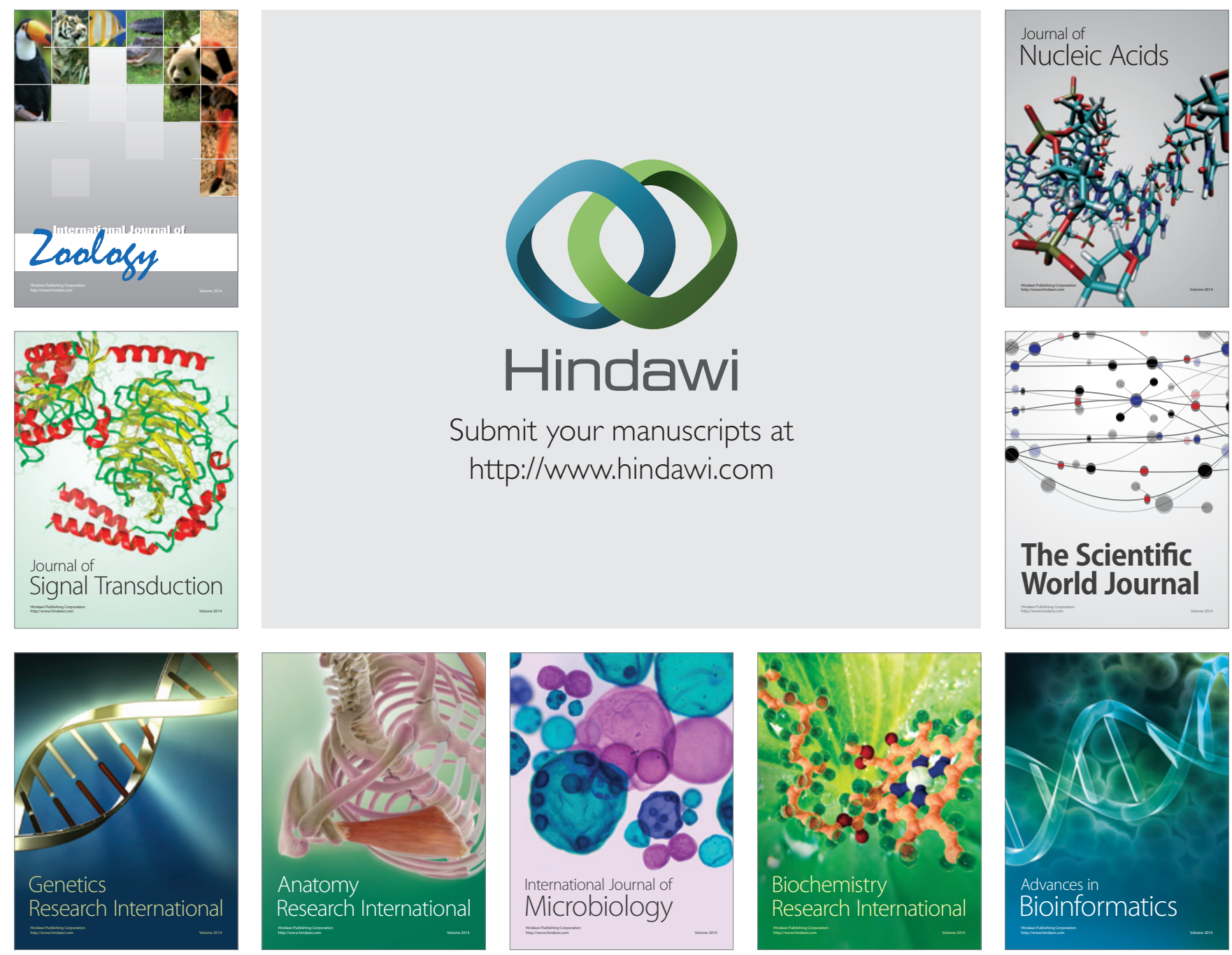

The Scientific World Journal
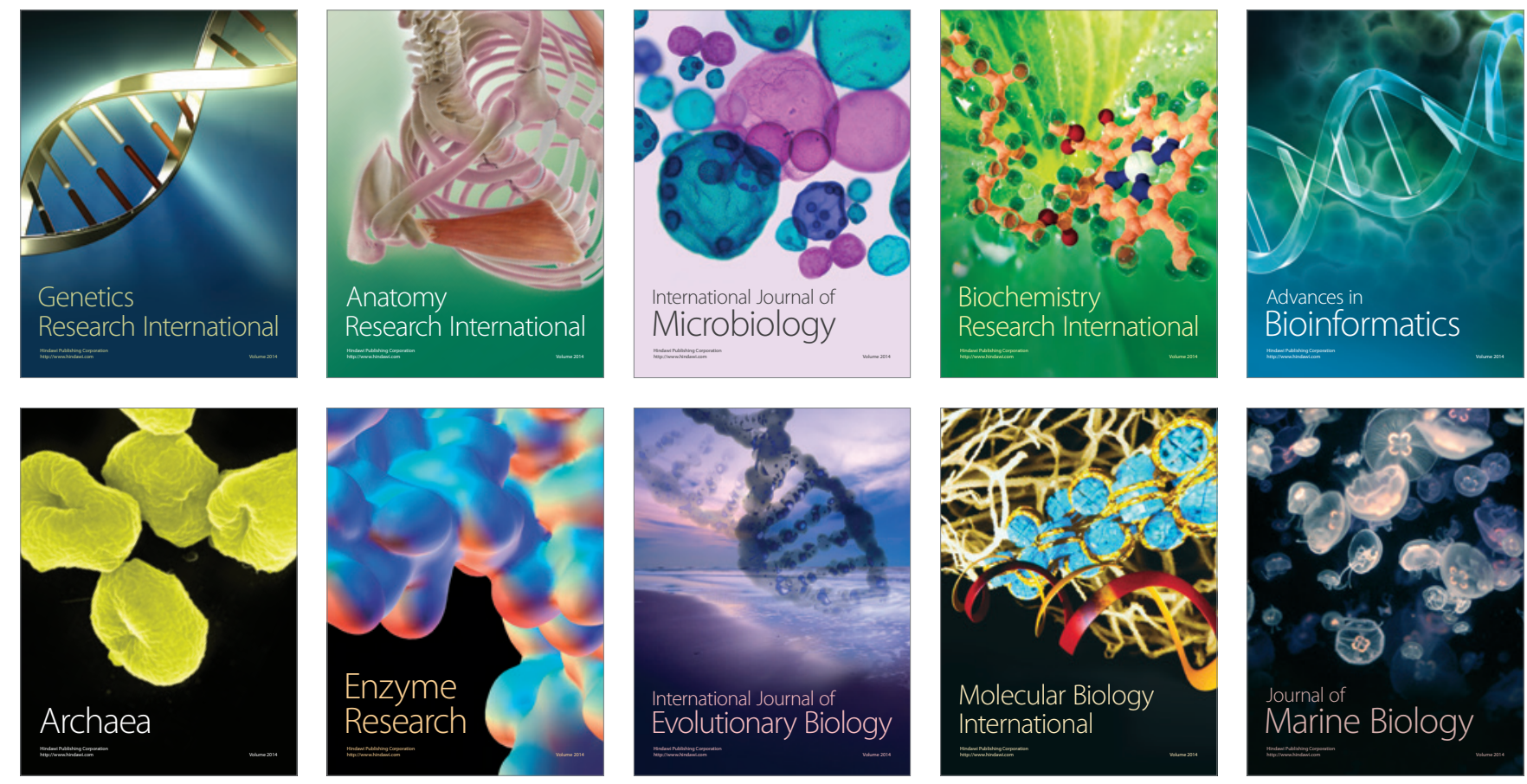